\title{
Googling the Guggul (Commiphora and Boswellia) for Prevention of Chronic Diseases
}

\section{OPEN ACCESS}

Edited by:

Atanas G. Atanasov,

Institute of Genetics and Animal

Breeding (PAS), Poland

Reviewed by:

Gokhan Zengin,

Selçuk University, Turkey

Ajay Bommareddy,

Wilkes University, United States

*Correspondence:

Ajaikumar B. Kunnumakkara kunnumakkara@iitg.ac.in

Bharat B. Aggarwal

bbaggarwal@gmail.com

Specialty section:

This article was submitted to

Ethnopharmacology,

a section of the journal

Frontiers in Pharmacology

Received: 15 January 2018

Accepted: 06 June 2018

Published: 06 August 2018

Citation:

Kunnumakkara $A B$, Banik K,

Bordoloi D, Harsha C, Sailo BL,

Padmavathi G, Roy NK, Gupta SC and Aggarwal BB (2018) Googling the

Guggul (Commiphora and Boswellia)

for Prevention of Chronic Diseases.

Front. Pharmacol. 9:686.

doi: 10.3389/fphar.2018.00686

\section{Ajaikumar B. Kunnumakkara ${ }^{1 *}$, Kishore Banik ${ }^{1}$, Devivasha Bordoloi ${ }^{1}$, Choudhary Harsha ${ }^{1}$, Bethsebie L. Sailo ${ }^{1}$, Ganesan Padmavathi ${ }^{1}$, Nand K. Roy ${ }^{1}$, Subash C. Gupta ${ }^{2}$ and Bharat B. Aggarwal ${ }^{3 *}$}

${ }^{1}$ Cancer Biology Laboratory, DBT-AIST International Laboratory for Advanced Biomedicine (DAILAB), Department of Biosciences and Bioengineering, Indian Institute of Technology Guwahati, Assam, India, ${ }^{2}$ Department of Biochemistry, Institute of Science, Banaras Hindu University, Varanasi, India, ${ }^{3}$ Inflammation Research Center, San Diego, CA, United States

Extensive research during last 2 decades has revealed that most drugs discovered today, although costs billions of dollars for discovery, and yet they are highly ineffective in their clinical response. For instance, the European Medicines Agency has approved 68 anti-cancer drugs, and out of which 39 has reached the market level with no indication of increased survival nor betterment of quality of life. Even when drugs did improve survival rate compared to available treatment strategies, most of these were found to be clinically insignificant. This is a fundamental problem with modern drug discovery which is based on thinking that most chronic diseases are caused by alteration of a single gene and thus most therapies are single gene-targeted therapies. However, extensive research has revealed that most chronic diseases are caused by multiple gene products. Although most drugs designed by man are mono-targeted therapies, however, those designed by "mother nature" and have been used for thousands of years, are "multitargeted" therapies. In this review, we examine two agents that have been around for thousands of years, namely "guggul" from Commiphora and Boswellia. Although we are all familiar with the search engine "google," this is another type of "guggul" that has been used for centuries and being explored for its various biological activities. The current review summarizes the traditional uses, chemistry, in vitro and in vivo biological activities, molecular targets, and clinical trials performed with these agents.

Keywords: guggul, guggulsterone, boswellia, boswellic acid, cancer, commiphora, chronic diseases

\section{INTRODUCTION}

Despite the remarkable advances made in the field of therapies for chronic diseases including cancer over the last few decades, they still present a major health burden and are the prime cause of death across the world. Most of the chronic illnesses are caused by the deregulation of multiple genes; however majority of the drugs approved by Food and Drug Administration (FDA) target single gene product or pathway only. This displays one of the major drawbacks of these synthetic drugs. In addition, these drugs are associated with different adverse side effects and hence not tolerable by patients (Siddiqui et al., 1984; Sarup et al., 2015; Kunnumakkara et al., 2017; Banik et al., 2018). Therefore, there is an urgent need to identify novel, safe, and multi-targeted agents for the prevention and treatment of these diseases (Bordoloi et al., 2016; Kunnumakkara et al., 2018). 
It has been well-evidenced that natural products are effective, multi-targeted, and extremely safe as they are the roots of many traditional systems of medicine such as Ayurveda, Unani, Siddha, traditional Chinese medicine etc. (Shishodia et al., 2008; Harsha et al., 2017). One such medicine of enormous use in Ayurveda is "Guggul." Guggul is the gum resin obtained from two different plants Commiphora and Boswellia, produced by drying the white sap of 15-20 years old tree for a year (Figure 1; Hanus et al., 2005).

The history of guggul goes as far back as 1700 BC. Ancient script on medicine and surgery; Sushrut Samhita, describes that guggul when taken orally can cure internal tumors, malignant sores, obesity, liver dysfunction, intestinal worms, leucoderma, sinus, and edema. It is also used as an Ayurvedic medicine for the prevention and treatment of various other diseases such as inflammatory bowel disease (IBD), ulcers, arthritis, cardiovascular diseases (CVDs), diabetes etc. (Shishodia et al., 2008). The main ingredients of guggul are guggulsterone (GS) and boswellic acid (BA) which are obtained from Commiphora and Boswellia respectively. It also contains a huge number of lignans and ketosterols, which contributes to the vivid health beneficiary effects of guggul (Arora et al., 1971, 1972; Kimura et al., 2001; Zhu et al., 2001; Francis et al., 2004).

According to Pubmed; "google," there are 449 publications on Commiphora, 519 on Boswellia, 207 on guggulsterone, 329 on boswellic acid, and 90 on guggul with earliest being in 1960 describing the "Antiarthritic and anti-inflammatory activity of the gum "guggul"; and in 1969 on "Analgesic effect of the gum resin from Boswellia serata." Some of the major species include Commiphora wightii (guggul), Commiphora mukul, Commiphora gileadensis, Boswellia serrata (salai guggul), Boswellia carterii, Boswellia sacra (source of frankincense \& gum resin), Boswellia ovalifoliolata, Boswellia dalzielii, Boswellia frerean, and Boswellia

\section{A Commiphora (Guggul)}


B Boswellia (Salai Guggul)
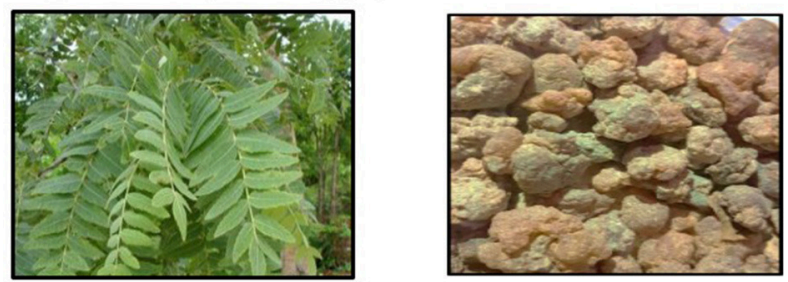

FIGURE 1 | (A) Commiphora (Mark W. Skinner/www.discoverlife.org) and Gum guggul (http://www.varionlife.com). (B) Boswellia (Pankaj Oudhia/www.discoverlife.org) and Salai guggul. thurifera. What is common among all these plants and their products is that all of them exhibit anti-inflammatory activities, although to a variable extent. The current review describes the traditional uses, chemistry, molecular targets, in vitro, in vivo and clinical studies of guggul isolated from Commiphora and Boswellia.

\section{SOURCE AND CHEMICAL CONSTITUENTS OF COMMIPHORA AND BOSWELLIA}

The guggul tree which belongs to the family Burseraceae, is mainly found in the dry regions of the Indian subcontinent mainly India, Pakistan and Bangladesh. The oleogum resin of C. mukul (guggul tree) is a yellowish substance that is tapped during winter and $\sim 700-900 \mathrm{~g}$ of resin is obtained from each tree (Deng, 2007; Shishodia et al., 2015; Yamada and Sugimoto, 2016). The guggul or balsam or the oleo gum resin is found in the balsam canals in the phloem of the large veins of leaf and base of the stem. It is a complicated mixture of minerals, gum, terpenes, sterols (Guggulsterol -I,-II,III,-IV,-V), essential oils, sterones (Z-, E-, M-guggulsterone, and dehydroguggulsterone-M), ferrulates, lignans, and flavanones. The ethyl acetate soluble fraction also known as guggulipid, consists of various bioactive components like diterpenoids, triterpenoids, steroids, lignans, and fatty tetrol esters. Based on the $\mathrm{pH}$ gradient, further fractionation yields $95 \%$ neutral, $4 \%$ acidic, and $1 \%$ basic fractions. The neutral fraction when subjected to further fractionation produces $88 \%$ non-ketonic and $12 \%$ ketonic fractions. A large number of steroids including the two isomers E-(cis-) and Z-(trans-) GS [4, 17(20)-pregnadiene3,16 -dione] were obtained from the ketonic fraction. Nearly $5 \%$ guggulipid and $2 \%$ gum guggul by weight is present in the GS (Figure 2A; Deng, 2007; Shishodia et al., 2008, 2015; Sarup et al., 2015).

Phenolics are common natural products found in plants and possess substantial antioxidant and anti-inflammatory effects. Various phenolic compounds such as hydroxybenzoic acid derivatives such as gallic acid, protocatechuic acid, gentisic acid, vanillic acid, p-hydroxy benzoic acid, syringic acid, ellagic acid, and cinnamic acid derivatives which include caffeic acid, chlorogenic acid, ferulic acid, sinapic acid (SA), and p-coumaric acid are largely present in plants. These phenolic compounds are predominantly available in guggul as well, which in part contributes to its immense biological function against diverse human chronic diseases (Hazra et al., 2018).

Guggulsterone is the only known antagonist of farnesoid $\mathrm{X}$ receptor (FXR). This FXR, also known as NR1H4 (nuclear receptor subfamily 1 , group $\mathrm{H}$, member 4 ), is a bile acid receptor (BAR). Bioinformatics studies (molecular docking simulation) revealed that GS binds to FXR and nuclear factor-kappa B $(\mathrm{NF}-\kappa \mathrm{B})$ and it docks into two non-canonical binding sites of FXR, helix 1-loop-helix 2 loop and parts of helix-helix 8 including helix 8-loop-helix 9 (Meyer et al., 2005; Yang et al., 2014). Different bile acids and chenodeoxycholic acids act as natural ligand for FXR, whose expression is elevated in the liver and intestine. When FXR binds to its ligand, it gets activated 


\section{A Commiphora (Guggul)}

\section{1) Sterones}

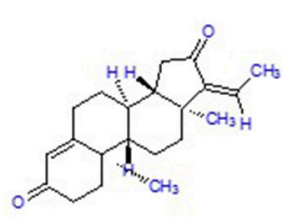

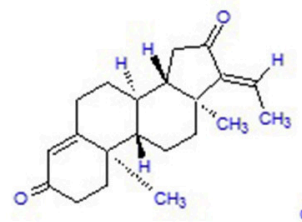



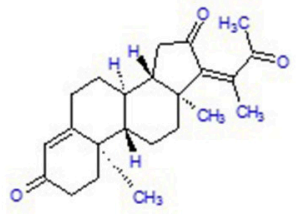

(Z)-Guggulsterone

(E)-Guggulsterone

Dehydroguggulsterone M

\section{Guggulsterone M}

2) Sterols

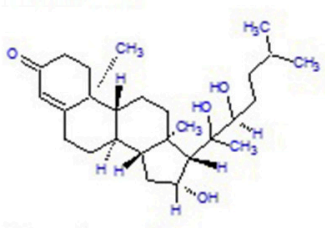

Guggulsterol I



Guggulsterol III

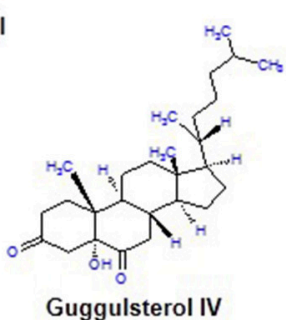

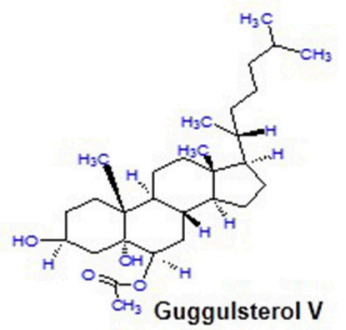

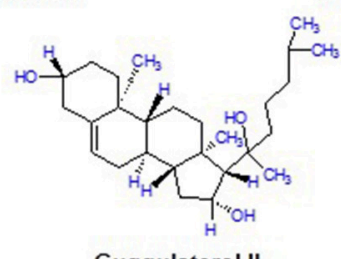

Guggulsterol II

Guggulsterol IV

\section{B Boswellia (Salai Guggul)}

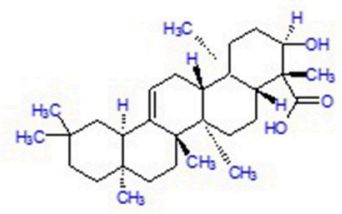

a-Boswellic Acid

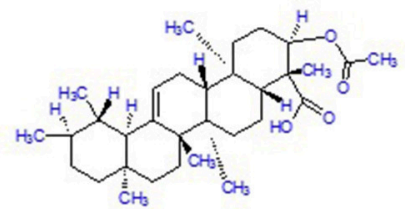

3-Acetyl- $\beta$-boswellic acid

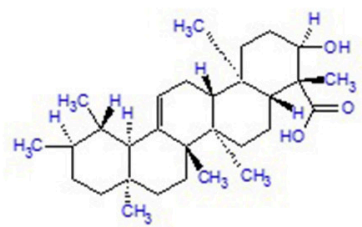

$\beta$ - Boswellic Acid

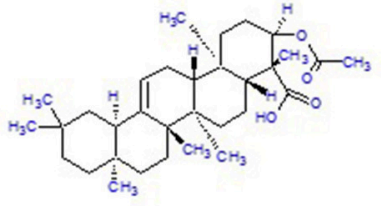

3-O-Acetyl-a-boswellic acid

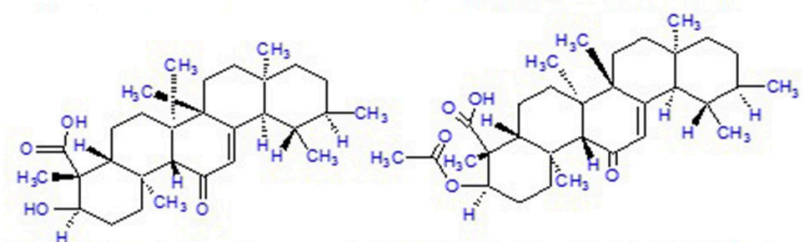

11-Keto-ß-boswellic acid

FIGURE 2 | Chemical constituents of Commiphora (guggul) and Boswellia (Salai guggul) (A) Commiphora (B) Boswellia.

and reaches the cell nucleus, where it forms a heterodimer with RXR. This heterodimer binds to the hormone response elements on DNA and regulates various genes. FXR activation downregulates cholesterol 7 alpha-hydroxylase (CYP7A1), the rate-limiting enzyme in bile acid synthesis from cholesterol by inducing the expression of small heterodimer partner (SHP) which in turn inhibits the transcription of CYP7A1 gene. While obeticholic acid, fexaramine, cafestol, and chenodeoxycholic acid act as agonist of FXR; GS, from the gum resin of guggul has also been confirmed to inhibit pro-inflammatory signals, together with transcription factor NF-кB (Sharma and Sharma, 1977; Urizar et al., 2002; Shishodia et al., 2008; Yamada and Sugimoto,
2016). Another study reported that the inhibitory activity of NF- $\kappa \mathrm{B}$ is due to the binding of GS to the RH domain of NF- $\kappa \mathrm{B}$ precursor protein $\mathrm{p} 105$ containing important sequences for DNA binding and dimerization (Khan et al., 2013).

B. serrata, commonly known as salai guggul, Indian olibanum, loban, or kundur, belongs to the Burseraceae family and is found in dry mountainous regions of India, Northern Africa, and the Middle East. Burseraceae family includes 17 genera and 600 species of plants. The genus Boswellia has 25 different species distributed throughout the tropical regions. B. serrata is one such medicinal plant which exhibits immense potential to combat various chronic disorders. The active pharmacological principle 
of the oleo gum resin from the trees of different Boswellia species is the BA (Büchele et al., 2003; Du et al., 2015; Roy et al., 2016). The gum resin of the Boswellia species mainly consists of mucus, resin acids, and volatile oil with different quantitative composition from species to species. The gum resin of salai guggul contains pentacyclic triterpenic acids, namely $\alpha$-boswellic acids, $\beta$-boswellic acids, $\gamma$-boswellic acid, acetyl- $\beta$ boswellic acid, 11-keto- $\beta$-boswellic acid (KBA), acetyl-11-keto$\beta$-boswellic acid (AKBA), and tetracyclic triterpenic acids like tirucallic acids viz 3-oxotirucallic acid, 3-hydroxytirucallic acid, and 3-acetoxytirucallic acid (Figure 2B). Other oleo gum resin compounds which display biological activities are: betulinic acid, lupenoic acid, epi-lupeol, isoincensole, isoincensole acetate and 1-ursene-2-diketone-incensole acetate along with few other terpenes that can be found in volatile oil (Du et al., 2015; Ammon, 2016; Roy et al., 2016).

\section{MOLECULAR TARGETS OF COMMIPHORA AND BOSWELLIA}

GS suppresses the physiological action of the FXR which is a nuclear hormone receptor that controls the synthesis and transport of bile acid (Sinal and Gonzalez, 2002; Urizar et al., 2002). However, it increases the transcription of bile salt export pump (BSEP) which is majorly involved in hepatic bile acid transport (Cui et al., 2003). Besides regulating transport of bile acid, GS is a potent anti-inflammatory agent which suppresses LPS-induced NO production (Meselhy, 2003). GS has also been reported to inhibit the activation of NF- $\kappa$ B by suppressing the levels of receptor activator of NF- $\kappa$ B ligand (RANKL) (Ichikawa and Aggarwal, 2006). In 2004, Shishodia and group reported that GS suppressed the activation of NF- $\kappa \mathrm{B}$ and I $\kappa \mathrm{B}-\alpha$ kinase and exhibited antiproliferative activity by inhibiting c-Myc and cyclin D1. Furthermore, GS has also been found to exert antimetastatic effect through reducing the levels of MMP-9, COX2, and VEGF (Shishodia and Aggarwal, 2004). This group also reported that GS induced apoptosis by modulating the expression of anti-apoptotic genes, IAP1, XIAP, Bcl-2, cFLIP, Bfl-1/A1, and survivin (Shishodia and Aggarwal, 2004). Further, GS has also been found to induce tumor cell apoptosis by activating the apoptotic genes, caspase-3,-8,-9, and inducing the release of cytochrome c, cleavage of bid and PARP. This was controlled by activated mitogen-activated protein kinase 4 (MKK4) mediated upregulation of c-Jun N-terminal kinase (JNK) and suppression of Akt. The antiproliferative activity of GS was found to be supported by reduced levels of cyclin D1, cdc2, and simultaneous upregulation of cyclin-dependent kinase inhibitors p21 and p27 (Figure 3A; Shishodia et al., 2007).

Boswellic acid is known to inhibit leukotriene synthesis by inhibiting 5-lipoxygenase (5-LOX) (Safayhi et al., 1992, 1995; Ammon et al., 1993). This 5-LOX inhibitor has also been found to reduce the activity of human leukocyte elastase (HLE) in vitro (Safayhi et al., 1997). Suppression of these molecules contributes to anti-inflammatory action of Boswellia. Boswellia is also known to induce apoptosis in cancer cells. In 2007, Bhushan and group reported that a triterpenediol from $B$. serrata induced apoptosis in HL-60 cells through both intrinsic and extrinsic pathways (Bhushan et al., 2007). In the first case, the triterpenediol was found to disturb the mitochondrial membrane potential, reduce $\mathrm{Bcl}-2 / \mathrm{Bax}$ ratio and cause release of AIF, Smac/DIABLO, and cytochrome $\mathrm{c}$ from the mitochondria along with suppression of survivin and upregulation of caspases-3, -8 , and-9, thereby leading to the cleavage of ICAD and PARP while in the second case, the oxidative stress generated in the cells due to excessive ROS and NO production triggered the activation of TNF-R1 and DR4 followed by activation of caspase-8. Another study in multiple myeloma cells also suggested that BA acetate induces apoptosis by upregulating death receptor proteins, DR4 and DR5 which subsequently leads to the activation of caspase- 8 followed by caspase-3 (Xia et al., 2005). The role of DR5-mediated pathway which involves activation of CAAT/enhancer binding protein homologous protein (CHOP) was reported in AKBA-mediated apoptosis of prostate cancer cells (Lu et al., 2008). Caspase-8 activation has also been reported in other BA-induced apoptosis studies (Liu et al., 2002a,b). In 2002, Park et al. hypothesized that $\mathrm{AKBA}$ contributed in the process of proliferation and apoptosis of tumors by inhibiting platelet-derived growth factor (PDGF)stimulated extracellular signal-regulated kinase 1 and 2 (ERK-1 and ERK-2) (Park et al., 2002b). BA mediated apoptosis has also been evident in cancer cells via activation of p21, an important cell cycle regulator protein (Glaser et al., 1999; Liu et al., 2006). Apart from this, AKBA has been found to interfere with IL-6induced STAT3 signaling via protein tyrosine phosphatase SHP-1 subsequently causing downregulation of cyclin D1, Bcl-2, Bcl$\mathrm{xL}, \mathrm{Mcl}-1$, and VEGF, thus impeding proliferation, survival and angiogenesis of multiple myeloma cells (Kunnumakkara et al., 2009). Moreover, BA has also been found to suppress metastatic growth factor, basic fibroblast growth factor (bFGF), chemokine receptor; CXCR4 and angiogenic factor; VEGFR 2 (Singh et al., 2007; Pang et al., 2009; Park et al., 2011a). Further, in vivo studies have unveiled that $\mathrm{BA}$ regulates proliferation and metastasis of cancer cells by downregulating other targets like COX-2, c-Myc, cyclin D1, MMP-9, VEGF, ICAM-1, Bcl-2, Bcl-xL, survivin, and cellular inhibitor of apoptosis protein 1 (IAP-1) (Park et al., 2011a,b; Yadav et al., 2012). Most of these genes are regulated by the transcription factor, NF- $\mathrm{B}$ which is also downregulated by BA (Syrovets et al., 2005a,b; Takada et al., 2006). Furthermore, BA has also been shown to regulate the activity of P-glycoprotein (Pgp) which is an important class of drug transporters (Weber et al., 2006). It is also an inhibitor of topoisomerases I and II in cancer cells (Hoernlein et al., 1999; Syrovets et al., 2000; Zhao et al., 2003). The anticancer activity of this potential compound also involves regulation of let-7 and miR-200 microRNA family (Figure 3B; Takahashi et al., 2012).

\section{THERAPEUTIC PROPERTIES OF GUGGUL}

Congregate evidences show guggul to be profoundly effective against diverse chronic diseases such as Alzheimer's disease, arthritis, cancer, pancreatitis, IBD, dermatitis, diabetes, infectious diseases, intestinal metaplasia, otitis media, respiratory diseases, asthma, psoriasis, gingivitis etc. Besides, it also 

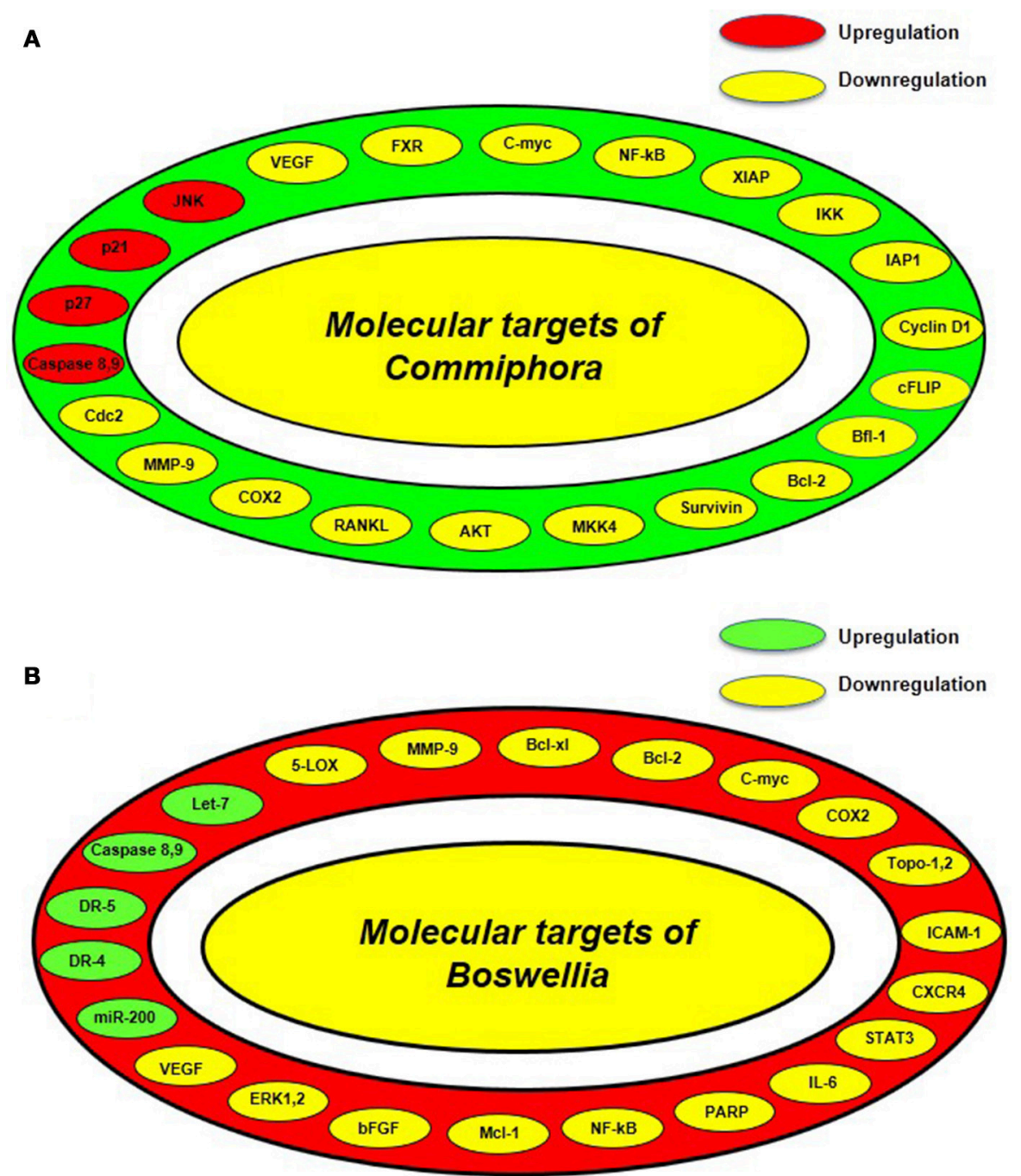

FIGURE 3 | Various molecular targets of guggul from Commiphora and Boswellia (A) Molecular targets of guggul from Commiphora includes Bcl2, B-cell lymphoma 2; CDC 2, cell division cycle kinase 2; C-FLIP, cellular caspase-8 (FLICE)-like inhibitory protein; COX, cyclooxygenase; FXR, farnesoid X receptor; IKK, IKB kinase; IAP, Inhibitors of apoptosis proteins; JNK, C-Jun N-terminal kinase; MKK4, mitogen-activated protein kinase kinase 4; MMP, matrix metalloproteinase; NF-KB, nuclear factor-kB; RANKL, Receptor activator of nuclear factor kappa-B ligand; VEGF, vascular endothelial growth factor; XIAP, $x$-linked inhibitor of apoptosis protein. (B) Molecular targets of guggul from Boswellia includes Bcl-2, B-cell lymphoma 2; Bcl-xL, B-cell lymphoma-extra-large; CXCR-4, C-X-C chemokine receptor type 4;

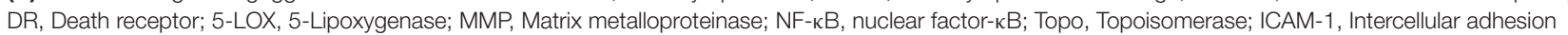
molecule 1; STAT-3, Signal transducer and activator of transcription 3; IL-6, Interleukin 6; PARP, Poly ADP ribose polymerase; Mcl-1, Myeloid leukemia cell differentiation protein; bFGF, Basic fibroblast growth factor; ERK-1,-2, Extracellular signal-regulated kinases.

exerts hepatoprotective, neuroprotective, anti-inflammatory, anti-oxidant, cardioprotective, hypolipidemia, and thyroid stimulatory effect by targeting multiple signaling pathways (Table 1; Figure 4).

\section{IN VITRO STUDIES WITH COMMIPHORA AND BOSWELLIA AND THEIR ROLE IN DIFFERENT CHRONIC DISEASES}

Numerous in vitro studies have indicated the efficiency of guggul against diverse chronic diseases including cancer (Shishodia et al., 2007, 2008; Singh S. V. et al., 2007; Shah et al., 2012; Roy et al.,
2016). GS induced apoptosis in cancer cells via inhibition of NF- $\kappa$ B, activation of JNK and downregulation of Akt and antiapoptotic proteins (Shishodia and Aggarwal, 2004; Shishodia et al., 2007). Treatment with GS led to the inhibition of DNA synthesis and proliferation of leukemia cells via downregulation of cyclin D1, cdc2, and upregulation of p21 and p27 (Samudio et al., 2005; Shishodia et al., 2007). In addition, B. serrata gum resin displayed cytostatic and apoptosis-inducing effect against leukemia and brain tumor cells (Hostanska et al., 2002). Further, GS induced cell death in prostate cancer cells by reactive oxygen intermediate (ROI)-dependent activation of JNK, p38 MAPK and also activation of ERK1/2 (Singh S. V. et al., 2007; Xiao and Singh, 2008). Additionally, AKBA inhibited the proliferation and 
TABLE 1 | In vitro biological activities of guggul (Commiphora and Boswellia) against various chronic diseases.




TABLE 1 | Continued

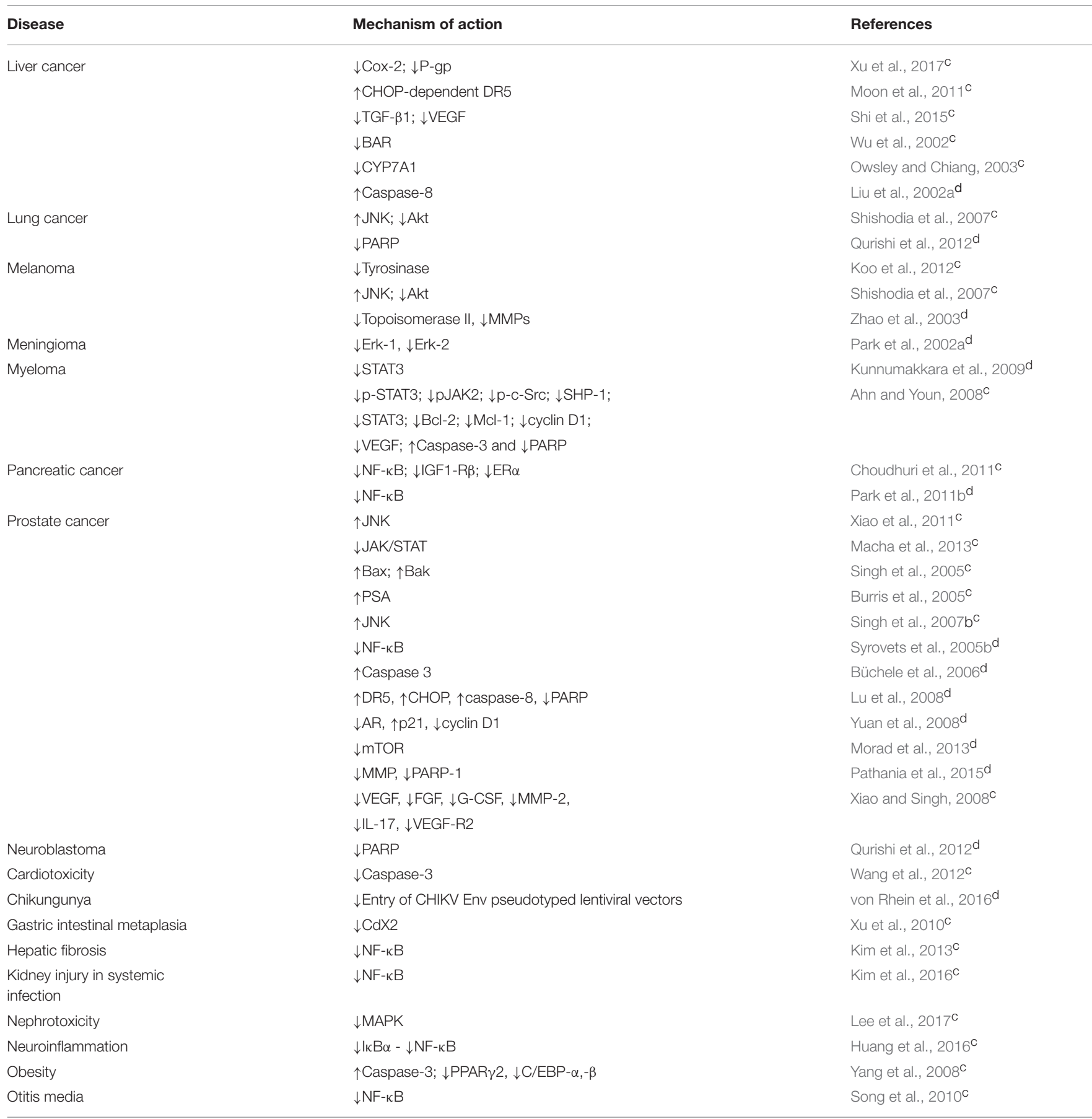

AR, Androgen receptor; ATF3, Activating transcription factor 3; BAR, Bile acid receptor; BCRP, Breast cancer resistance protein; C, Commiphora; C/EBP, CCAAT/enhancer binding protein; CDK, Cyclin dependent kinase; CdX2, Caudal-related homeobox 2; CHOP, CAAT/enhancer binding protein homologous protein; COX-2, Cyclooxygenase-2; CYP7A1, Cholesterol 7alpha-hydroxylase; d, Boswellia; DDIT3, DNA damage inducible transcript 3; DNMT, DNA methyl-transferase; DR, Death receptor; EGR1, Early growth response 1; ERa, Estrogen receptor alpha; FXR, Farnesoid X receptor; G-CSF, Granulocyte colony-stimulating factor; HO-1, Heme oxygenase-1; Hsp90, Heat shock protein 90; IGF1, Insulin-like growth factor 1; JNK, c-Jun N-terminal kinase; IL, Interleukin; IRF3, Interferon-regulatory factor 3; MAPK, Mitogen-activated protein kinase; MCL-1, myeloid leukemia cell differentiation protein; MDR, Multidrug resistance; MMP, Matrix metalloproteinases; MRP, Multidrug resistance protein; $m T O R$, Mechanistic target of rapamycin; NF-kB, Nuclear factor kappa B; Nrf-2, The nuclear factor erythroid 2 (NFE2)-related factor 2; PARP, Poly ADP ribose polymerase; PI3K, Phosphatidylinositol-4,5-bisphosphate 3-kinase; PPAR, Peroxisome proliferator activated receptor; pRb, phosphorylated Retinoblastoma; PS, Phosphatidylserine; PSA, Prostate-specific antigen; RANKL, Receptor activator of nuclear factor kappa-B ligand; ROS, Reactive oxygen species; SAMD14, Sterile Alpha Motif Domain Containing 14; SHP-1, Src homology region 2 domain-containing phosphatase-1; SMPD3, Sphingomyelin phosphodiesterase 3; STAT, Signal transducer and activator of transcription 6; STAT3, Signal transducer and activator of transcription 3; TGF, Transforming growth factor; TLR-3, Toll-like receptor-3; TLR-4, Toll-like receptor-4; VEGF, Vascular endothelial growth factor; VEGFR2, Vascular endothelial growth factor receptor 2; XIAP, X-linked inhibitor of apoptosis protein. 




FIGURE 4 | In vitro, in vivo and clinical studies on the biological activities of guggul against diverse chronic diseases.

induced apoptosis in colon cancer cells through p21 and caspase8 dependent pathway (Liu et al., 2002b, 2006). Besides, it also modulated the expression of let-7, miR-200 families and their downstream targets in colon cancer cells (Takahashi et al., 2012).

Apart from cancer, the effect of guggul has been well proven against different inflammatory diseases such as rheumatoid arthritis, IBD, and various other diseases such as obesity, otitis media, uveitis etc. For example, treatment with GS downregulated RANKL induced osteoclastogenesis and blocked IL-1beta mediated production of chemokines and epithelial neutrophil activating peptide-78 (ENA-78), MMP-1,-3 via suppression of NF- $\kappa \mathrm{B}$, nuclear p50, and p65 subunit and I $\mathrm{B} \alpha$ degradation in rheumatoid arthritis (Ichikawa and Aggarwal, 2006; Kinne et al., 2007; Lee et al., 2008; Ammon, 2016). A study conducted by Cheon and group on IBD showed that GS inhibited IL-1beta- or lipopolysaccharide (LPS)- induced ICAM-1 expression, NF- $\kappa \mathrm{B}$ transcription activity and IКB phosphorylation/degradation in human Caco-2 cells and rat nontransformed IEC-18 cells (Cheon et al., 2006). Further, treatment with GS alone showed increase in apoptosis and lipolysis and its combination with genistein resulted in increased cleavage of procaspase-3, PARP, expression of Bax, release of cyt-c and prevented lipid accumulation in maturing adipocytes resulting in inhibition of adipogenesis (Yang et al., 2007, 2008). GS exerted its effect against otitis media, the foremost cause of hearing impairment in children by inhibiting LPS-induced upregulation of TNF- $\alpha$ expression, COX-2 production and I $\kappa \mathrm{B} \alpha$ degradation (Ovesen and Ledet, 1992; Barrett et al., 2003; Song et al., 2010). In case of uveitis, treatment with GS inhibited LPS-induced expression of inflammatory proteins in human primary nonpigment ciliary epithelial cells (Kalariya et al., 2010).

As guggul is an FXR antagonist, it is used extensively as a cholesterol-lowering agent (Rizzo et al., 2006; Shah et al., 2012). GS eliminated the effect of chenodeoxycholic acid (CDCA), an FXR agonist on the expression of Cdx2 and MUC2 and thus prevented bile acid induced gastric intestinal metaplasia and carcinogenesis (Xu et al., 2010). Oswley and Chiang reported that GS antagonizes FXR induction of BSEP but activates pregnane $\mathrm{X}$ receptor to inhibit CYP7A1 gene (Owsley and Chiang, 2003). In addition, Commiphora and Boswellia showed potent cardioprotective as well as thyroid-stimulatory effects (Singh et al., 1982; Deng, 2007). For instance, GS inhibited DOX induced cytotoxicity, reduced apoptosis, and intracellular ROS and formation of MDA in DOX-treated H9C2 cells (Wang 
et al., 2012). In addition, triterpenes and prenylaromadendranetype diterpenes from the gum resin of $B$. carterii was shown to exert hepatoprotective effect against d-galactosamine-induced liver cell damage (Wang et al., 2013, 2016).

\section{IN VIVO STUDIES WITH COMMIPHORA AND BOSWELLIA AND THEIR ROLE IN DIFFERENT CHRONIC DISEASES}

Promising after effects of Commiphora and Boswellia against various chronic diseases in the in vitro setting has led to a handful of in vivo studies where the efficacy of guggul was evaluated in different experimental models of diverse chronic diseases such as cancer, inflammatory, cardiovascular, and metabolic diseases, atherosclerosis, asthma etc. (Table 2; Figure 4). Recently, several studies have reported the anti-tumor efficacy of guggul in different cancers such as cancers of breast, esophagus, head, and neck, pancreas, prostate etc. (An et al., 2009). For instance, AKBA was found to prevent intestinal tumorigenesis and exert chemopreventive effect via inhibition of $w n t / \beta$-catenin and NF- $\mathrm{kB} / \mathrm{COX}-2$ signaling pathways (Liu et al., 2013; Wang R. et al., 2014). Another study showed AKBA to function via modulation of let-7 and miR-200 downstream genes in colorectal (CRC) tumors (Takahashi et al., 2012). In case of breast cancer, treatment with GS increased the chemosensitivity of MCF-7/DOX cells to doxorubicin in vivo through inhibition of Bcl-2 and Pgp (Xu et al., 2014b). In addition, GS suppressed esophageal tumor cell viability via inhibition of FXR and prevented the growth of esophageal cancer cells significantly in combination with amiloride in vivo (Guan et al., 2013, 2014). Furthermore, in case of glioma, cyano enone of methyl boswellates (CEMB), and 3- $\alpha$-propionyloxy- $\beta$ boswellic acid (POBA) significantly inhibited the tumor growth in murine models (Ravanan et al., 2011; Qurishi et al., 2013). Again, topical application of Boswellin (BE); B. serrata gum resin exudate inhibited skin inflammation, epidermal proliferation, and tumor promotion induced by 12-O-tetradecanoylphorbol13-acetate (TPA) in 7,12-dimethylbenz[a] anthracene (DMBA)initiated mice. Additionally, treatment with guggulipid was shown to cause reduced growth of HNSCC cells in vivo (LeemanNeill et al., 2009). Besides, GS enhanced the antitumor efficacy of gemcitabine in pancreatic cancer via modulation of Akt, NF$\kappa \mathrm{B}$, and apoptosis-related proteins (Ahn et al., 2012). In case of prostate cancer as well, guggul has been found to be highly effective in vivo (Syrovets et al., 2005b; Büchele et al., 2006; Pang et al., 2009; Pathania et al., 2015). Oral administration of guggulsterone prevented in vivo angiogenesis of prostate cancer cells through suppression of VEGF-VEGF-R2-Akt signaling (Xiao and Singh, 2008).

Apart from cancer, the efficacy of guggul was well proven in different inflammatory diseases such as arthritis, colitis, gastritis, IBD, pancreatitis, uveitis etc. (Sharma et al., 1989; Cheon et al., 2006; Xiao and Singh, 2008; Mencarelli et al., 2009; Kalariya et al., 2010; Kim et al., 2010, 2013; Dhaneshwar et al., 2013; Kang et al., 2013; Wang R. et al., 2014). In case of rheumatoid arthritis, treatment with guggul decreased the thickness of joint swelling, reduced the infiltration of leucocytes into the pleural cavity, suppressed the pro-inflammatory cytokines and increased betaglucuronidase activity in vivo (Sharma and Sharma, 1977; Reddy and Dhar, 1987; Sharma et al., 1989; Fan et al., 2005). In addition, guggul reduced the severity of IBD via inhibition of LPS- or IL-1beta-induced ICAM-1 gene expression and NF- $\kappa$ B activity (Krieglstein et al., 2001; Cheon et al., 2006; Mencarelli et al., 2009; Kim et al., 2010). Furthermore, administration of GS resulted in mitigation of histological damage, suppressed serum lipase levels, inhibition of infiltrations of neutrophils, and macrophages and decreased cytokine production in pancreatitis (Kim et al., 2015). Moreover, GS inhibited the expression of endotoxin-induced uveitis (EIU)-associated inflammatory markers such as MMP-2, $\mathrm{NO}$, and prostaglandin $\mathrm{E}_{2}\left(\mathrm{PGE}_{2}\right)$ (Kalariya et al., 2010).

Guggul exhibited profound cardioprotective effects as well in vivo (Chander et al., 2003). It decreased the lipid peroxide, creatine phosphokinase, phospholipase, xanthine oxidase activities, and total cholesterol level in the serum; increased superoxide dismutase (SOD), myocardial antioxidants, glutathione peroxidase (GSHPx), catalase (CAT); reduced glutathione (GSH), creatine-phosphokinase-MB (CK-MB), and lactate dehydrogenase (LDH) as well as reversed the cardiac damage induced by isoproterenol (Kaul and Kapoor, 1989; Batra et al., 2000; Ojha et al., 2011). The hypolipidemic effect of guggul has also been well studied in different animal models (Khanna et al., 1969; Dixit et al., 1980; Baldwa et al., 1981; Lata et al., 1991). Guggul diminished hyperlipidemia via inhibition of FXR activation. In high-fat-diet-fed mice, treatment with GS improved blood glucose in fasting condition, plasma insulin level, glucose tolerance, level of harmful lipids, phosphoenol pyruvate carboxykinase, glucose-6-phosphatase, and other proteins like glucose transporter-4, PPARc, and TNF- $\alpha$ (Satyavati et al., 1969; Singh et al., 1990; Urizar et al., 2002; Cui et al., 2003; Sharma et al., 2009; Tripathi, 2009). Further, C. opobalsamum, C. mukul, B. serrata, and B. ovalifoliolata species mitigated hepatic damage and displayed protective effect against lipid peroxidation and deviated serum enzymatic variables (Al-Howiriny et al., 2004; Y et al., 2006; Mahesh et al., 2014). In addition, GS reversed neuronal damage and memory deficits in mice by increasing glutathione level in the brains, antiacetylcholine esterase, and antioxidant activities (Saxena et al., 2007). Apart from these, administration of GS was found to increase thyroid function by enhancing iodine uptake, improved the activities of thyroid peroxidase, and protease and ameliorated hypothyroidism through its ability to increase thyroid hormone in vivo (Tripathi et al., 1975, 1984; Panda and Kar, 2005).

Taken together, these pre-clinical studies provide substantial evidence of the enormous potential of guggul as a multi-targeted agent for the prevention and treatment of different chronic diseases.

\section{CLINICAL STUDIES WITH COMMIPHORA AND BOSWELLIA AND THEIR ROLE IN DIFFERENT CHRONIC DISEASES}

Several clinical trials have been conducted to evaluate the effect of "guggul" from Commiphora and Boswellia on various chronic disorders. Human studies on guggul has 
TABLE 2 | In vivo biological activities of guggul (Commiphora and Boswellia) against various chronic diseases.

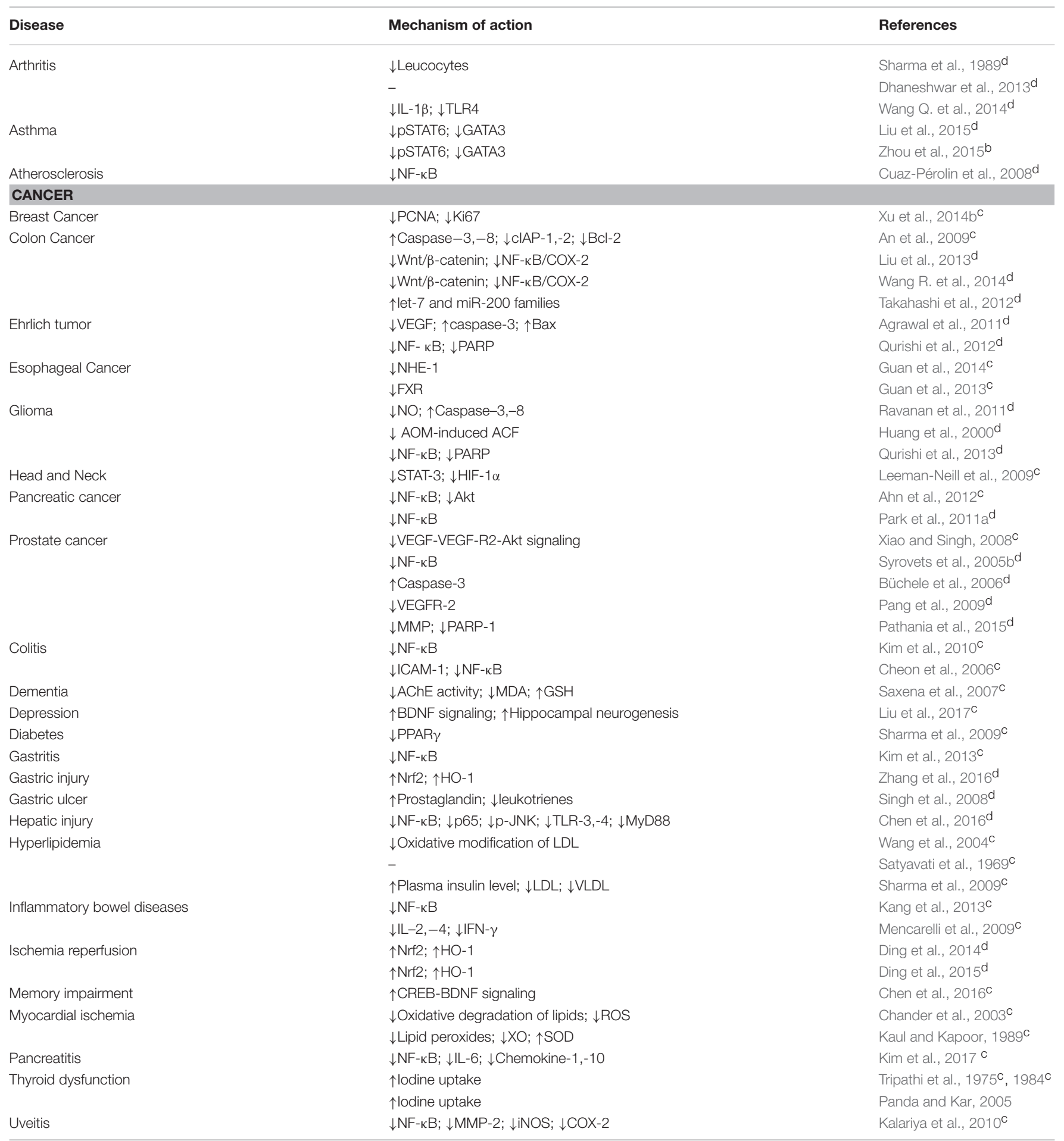



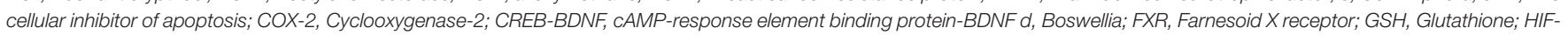

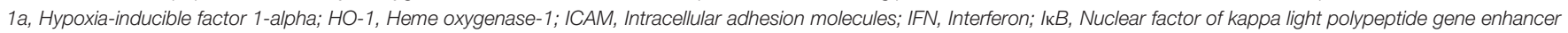

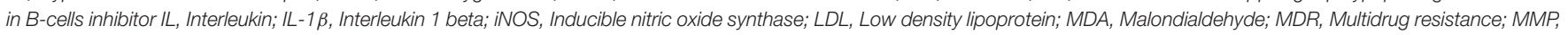

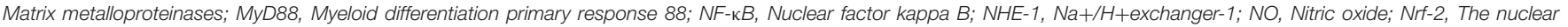

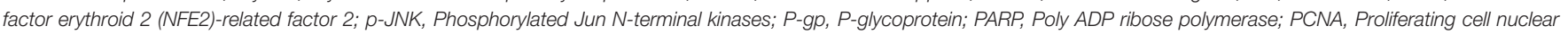

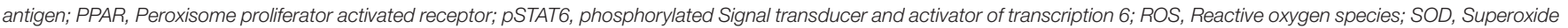

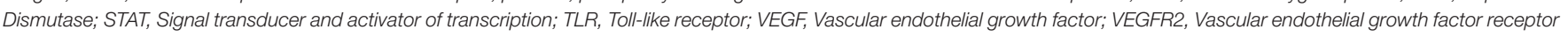
2; XO, Xanthine oxidase. 
been found to be effective against different diseases such as asthma, breast fibroadenoma, chronic kidney disease, colitis, Crohn's disease, fascioliasis, hepatitis C, hypercholesterolaemia, hyperlipidemia, metabolic syndrome, nodulocystic acne, arthritis, schistosomiasis, stress urinary incontinence etc. (Table 3; Figure 4).

\section{Arthritis}

Arthritis is mainly caused due to inflammation of joints, the tissues surrounding the joints and other connective tissues. Osteoarthritis is the most common form of arthritis which affects a wide range of people across all the places. As guggul has been reported to exhibit high affectivity against arthritis pre-clinically; hence, its effect was evaluated in the clinical setting as well. In one such study, 30 patients with arthritis were treated with gum guggul for 1 month which resulted in remarkable improvement in the total scores of Western Ontario and MacMaster Osteoarthritis Index and condition of the patients (Singh et al., 2003). Another study was conducted by Kimmatkar et al., to check the safety, tolerability, and efficacy of $B$. serrata extract in 30 patients with knee osteoarthritis. The patients receiving drug treatment reported a decrease in knee pain and swelling of the knee joint as well as increased knee flexion and walking distance (Kimmatkar et al., 2003).

\section{Asthma}

Asthma is a chronic multifactorial inflammatory disease of the respiratory tract and is one of the major health concern. Notably, Boswellia has been found to be effective in the treatment of this disease. In a clinical study, 40 patients having 23 males, and 17 females in the age range of 18-75 years, suffering from bronchial asthma were treated with $300 \mathrm{mg}$ of gum resin thrice daily for a period of 6 weeks. This led to improved prognosis in around $70 \%$ of the patients as various signs and symptoms of bronchial asthma like rhonchi, dyspnoea, and attacks disappeared upon treatment (Gupta et al., 1998).

\section{Breast Fibroadenomas}

Breast fibroadenoma accounts for the majority of breast lumps in young women. Boswellia was found to exert beneficial effect against breast fibroadenomas as evinced by a study conducted by Pasta and group. They showed that treatment with the combination of Boswellia, betaine, and myo-inositol resulted in decreased fibroadenoma dimension in young women without exerting any toxic effects. The combination also resulted in reduced fibroadenoma volume in $38.8 \%$ of the patients in the experimental group, whereas the same was observed only in $17.85 \%$ patients in the placebo group (Pasta et al., 2016).

\section{Cardiovascular Diseases (CVDs)}

CVDs, a group of diseases which involves the heart and the blood vessels is one of the most common causes of death across the globe. Notably, guggul presents a potent remedy for cardiovascular diseases. For example, Singh and group conducted a study to evaluate the cardioprotective benefits of guggul by enrolling 200 patients suffering from ischemic heart disease. The patients were treated with the combination of gum guggul and Inula racemosa for 6 months which resulted in the reduced levels of total cholesterol, triglyceride, and total blood lipids in the patients. It also restored the normal electrocardiogram (ECG) in $26 \%$ of the patients, showed improvement of ECG in 59\% of the patients and lessened the chest pain in $25 \%$ of the patients (Singh et al., 1993).

\section{Chronic Kidney Disease}

Chronic kidney disease (CKD) is a progressive disease where occurs due to enhanced inflammation and oxidative stress leading to reduced kidney function. Studies have indicated $B$. serrata in combination with Curcuma longa as an effective regimen to obtain reduced inflammation in patients with $\mathrm{CKD}$ which functioned via modulation of prostaglandin $\mathrm{E}_{2}\left(\mathrm{PGE}_{2}\right)$ (Shelmadine et al., 2017). Moreover, this regimen was found to be safe, well tolerated which also enhanced the levels of inflammatory cytokines in CKD patients (Moreillon et al., 2013).

\section{Diabetes Mellitus}

A large population of the world is affected by diabetes mellitus or type 2 diabetes. Several preclinical studies have shown that the gum resin of commiphora and boswellia are highly effective against this disease. In a clinical study conducted by Ahangarpour et al., it was observed that the treatment of patients with diabetes mellitus with B. serrata gum resin (900 mg daily for 6 weeks orally) resulted in decreased risk factors associated with this disease. Further, the treatment also helped in maintaining fructosamine levels, hepatic enzyme activities, and to bring lipid profiles close to normal levels in the patients (Ahangarpour et al., 2014).

\section{Eczema and Psoriasis}

Eczema, also known as dermatitis and psoriasis are caused mainly due to inflammation of the skin. Boswellia has been found to exert effectiveness against eczema and psoriasis. A group of scientists revealed that Boswellia-based cream lessens the use of topical corticosteroids and can diminish the grade of erythema and the skin superficial symptoms (Togni et al., 2015). Further, in a double blind study, the efficacy of a novel formulation of BA (Bosexil $^{\circledR}$ ) containing B. serrata resin extract and lecithin was evaluated against both psoriasis and eczema. Improvement in psoriasis, scales (70\% of cases), and erythema (50\% of cases) was observed with Bosexil ${ }^{\circledR}$ compared to placebo. In addition, when eczema patients were administrated with Bosexil ${ }^{\circledR}$ formulation, it showed improvement in both erythema ( $60 \%$ of cases) and itch ( $60 \%$ of cases) of the patients without any case of waning (Togni et al., 2014).

\section{Fascioliasis}

Fascioliasis is a parasitic worm infection caused by the common liver fluke Fasciola hepatica and Fasciola gigantica. The formulation of myrhh, the gum resisn of Commiphora molmol was reported to be safe, well tolerated, and effective for the management of this disease. The formulated drug comprised of 8 parts of resin and 3.5 parts of volatile oils, all extracted from myrrh. They observed that 7 patients who were passing fasciola 
TABLE 3 | Clinical trials of guggul (Commiphora and Boswellia) against various chronic diseases.

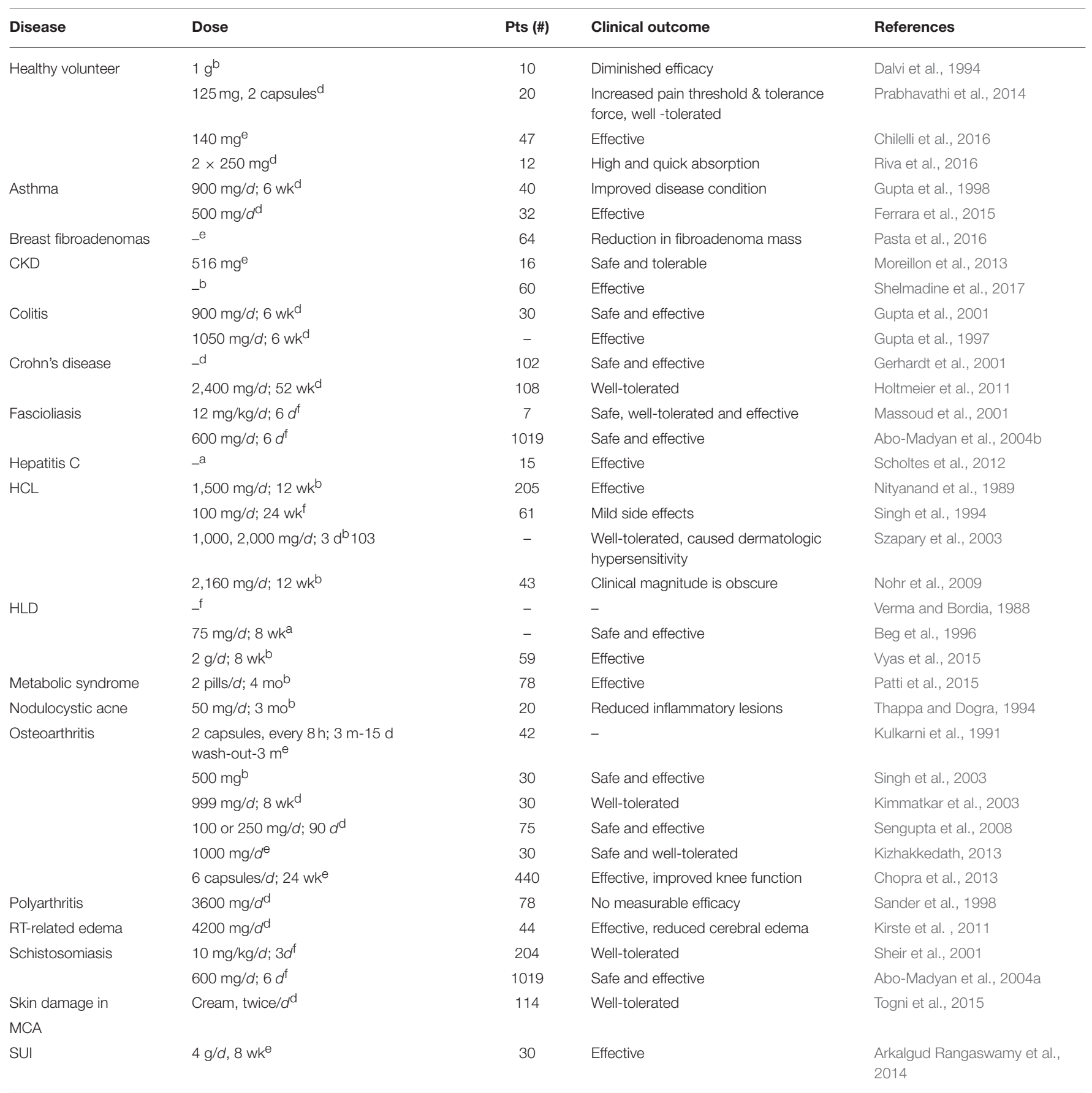

CKD, Chronic kidney disease; d, Day; HCL, Hypercholesterolemia; HLD, Hyperlipidemia; MCA, Mammary carcinoma; mo, Month; wk, Week; RT, Radiotherapy; SUI, Stress urinary incontinence; $a$, Gugglusterone; b, Guggul; c, Formulation of guggul; $d$, Boswellia; e, Formulation of Boswellia; $f$, Commiphora.

eggs in their stools displayed distinct improvement of the general condition, drop in the egg count, and improvement of all signs and symptoms with no adverse side effects after treatment with the drug (Massoud et al., 2001).

\section{Gingivitis}

Gingivitis, the inflammation of gingiva is a very common form of gum disease. Frankincense extract has been found to exhibit efficacy against gingivitis. A double blinded randomized placebo controlled trial was conducted among 75 female patients aged between 15 and 18 years with moderate plaque-induced gingivitis. Six groups were randomly formed based on the administration of $0.1 \mathrm{~g}$ of frankincense extract, $0.2 \mathrm{~g}$ of its powder, placebo, and whether the patients have undergone scaling and root planning (SRP) or not. Gingival index, plaque index, bleeding index, and probing pocket depth were measured on the 0,7 th, and 14th days of the study. Detailed analysis of the data revealed that SRP along with the application of 
frankincense extract or powder might cause significant decrease in inflammatory indices in comparison to the groups without drug therapy and SRP (Khosravi Samani et al., 2011).

\section{Inflammatory Bowel Disease}

Different clinical studies with guggul have shown its efficacy against IBDs which include colitis and Crohn's disease. For instance, the gum resin of $B$. serrata was found to be effective in the treatment of chronic colitis with minimal side effects in a clinical study conducted by Gupta et al. In this study, the patients with chronic colitis were treated with gum resin from B. serrata at a dose of $900 \mathrm{mg}$ daily divided in three doses for 6 weeks. The treatment resulted in the improvement of stool properties, hemoglobin, serum iron, calcium, phosphorus, proteins, total leukocytes, and eosinophils in the patients (Gupta et al., 2001). Further, a double-blind, placebo-controlled, randomized, parallel study on 82 patients with Crohn's disease was conducted where patients were given a new B. serrata extract; Boswelan. In this trial, remission was observed in $59.9 \%$ of the actively treated patients. Additionally, this study also confirmed better tolerability of Boswelan in long-term treatment of Crohn's disease (Holtmeier et al., 2011). Furthermore, leukotrienes play an important role in inflammation of the colon in ulcerative colitis. Sallai guggul gum resin is known to be specific, non-redox, and non-competitive inhibitors of 5-LOX, a crucial enzyme of leukotriene biosynthesis. Patients with grade II and III ulcerative colitis were treated with $B$. serrata gum resin at a dose of $350 \mathrm{mg}$ thrice daily for 6 weeks. Stool properties, histopathology, and scan microscopy of rectal biopsies, blood parameters including hemoglobin, serum iron, calcium, phosphorus, proteins, total leukocytes, and eosinophils showed slightly better improvement in Boswellia treated patients (Gupta et al., 1997).

\section{Nodulocystic Acne}

Guggulipid is considered to be very effective in topical and oral complementary as well as an alternative medicine (CAM) for the treatment of acne (Magin et al., 2006). In a clinical study conducted by Thappa and Dogra, patients with nodulocystic acne were given guggulipid equivalent to $25 \mathrm{mg}$ GS for 3 months, which resulted in progressive reduction in lesions in majority of patients. However, patients with oily faces displayed better response to guggulipid (Thappa and Dogra, 1994).

Thus, these clinical studies well evince the potential effect of Commiphora and Boswellia on different chronic diseases. However, more studies are inevitable to establish them as cutting edge strategy for the treatment of diverse human diseases.

\section{REFERENCES}

Abo-Madyan, A. A., Morsy, T. A., and Motawea, S. M. (2004a). Efficacy of Myrrh in the treatment of schistosomiasis (haematobium and mansoni) in Ezbet ElBakly, Tamyia Center, El-Fayoum Governorate, Egypt. J. Egypt Soc. Parasitol. $34,423-446$.

Abo-Madyan, A. A., Morsy, T. A., Motawea, S. M., and Morsy, A. T. (2004b). Clinical trial of Mirazid in treatment of human fascioliasis, Ezbet El-Bakly (Tamyia Center) Al-Fayoum Governorate. J. Egypt. Soc. Parasitol. 34, 807-818.

\section{CONCLUSION}

Since ancient times, Commiphora and Boswellia are considered as important traditional medicinal plants which are used for the treatment of various ailments. Guggul isolated from Commiphora and Boswellia have immense therapeutic potential against several diseases and it has been well established by numerous in vitro, in vivo, and clinical studies. Guggul was used traditionally for the treatment of inflammation and hyperlipidemia, but with the extensive studies on guggul and associated molecular mechanisms unveiled newer insights of its use for the treatment of various other chronic diseases as well. Gum resin guggul possesses multiple pharmacological activities especially hypolipidemic, antiobesity, anti-inflammatory, anti-tumor effects, cardioprotective, neuroprotective, hepatoprotective, thyroid stimulatory effects etc. It effectively regulates different transcription factors, enzymes, cytokines, and anti-apoptotic proteins which are involved in inflammation, carcinogenesis, and other chronic diseases. Further, Commiphora in combination with other ayurvedic herbs is commercially available and marketed for the treatment and cure of arthritis, obesity and associated side effects of the disease. Many patents are also filed and approved to use guggul as a constituent of polyherbal formulations and cosmetics. Therefore, taking the medicinal importance and commercial use of guggul into consideration, it can be advocated to possess substantial therapeutic potential against diverse chronic disorders. However, more in vitro, in vivo, and well-designed clinical studies are required to validate the clinical usefulness of guggul and to obtain a potent herbal derived drug with enhanced efficacy, minimal side effects and strong disease combating properties.

\section{AUTHOR CONTRIBUTIONS}

$\mathrm{BA}$ and $\mathrm{AK}$ contributed to study design and writing of the manuscript. $\mathrm{KB}$ and $\mathrm{DB}$ carried out literature survey, writing and artwork. $\mathrm{CH}, \mathrm{BS}$, and NR contributed to the making of the tables and artwork. SG and GP performed proofreading of the manuscript.

\section{ACKNOWLEDGMENTS}

This work was supported by BT/529/NE/TBP/2013 grant awarded to AK by Department of Biotechnology (DBT), Government of India. The author KB acknowledges UGC, New Delhi, India for providing the fellowship. The author BS acknowledges DST-INSPIRE for providing her the fellowship.

Agrawal, S. S., Saraswati, S., Mathur, R., and Pandey, M. (2011). Antitumor properties of Boswellic acid against Ehrlich ascites cells bearing mouse. Food Chem. Toxicol. 49, 1924-1934. doi: 10.1016/j.fct.2011.04.007

Ahangarpour, A., Heidari, H., Fatemeh, R. A., Pakmehr, M., Shahbazian, H., Ahmadi, I., et al. (2014). Effect of B. serrate supplementation on blood lipid, hepatic enzymes and fructosamine levels in type2 diabetic patients. J. Diabetes Metab. Disord. 13:29. doi: 10.1186/2251-6581-13-29

Ahn, D. W., Seo, J. K., Lee, S. H., Hwang, J. H., Lee, J. K., Ryu, J. K., et al. (2012). Enhanced antitumor effect of combination therapy with 
gemcitabine and guggulsterone in pancreatic cancer. Pancreas 41, 1048-1057. doi: 10.1097/MPA.0b013e318249d62e

Ahn, S. I., and Youn, H. S. (2008). Guggulsterone suppresses the activation of NF$\mathrm{kB}$ and expression of COX-2 induced by toll-like receptor 2, 3, and 4 agonists. Food Sci. Biotechnol. 17, 1294-1298.

Al-Howiriny, T. A., Al-Sohaibani, M. O., Al-Said, M. S., Al-Yahya, M. A., El-Tahir, K. H., and Rafatullah, S. (2004). Hepatoprotective properties of Commiphora opobalsamum ("Balessan"), a traditional medicinal plant of Saudi Arabia. Drugs Exp. Clin. Res. 30, 213-220. doi: 10.1055/s-0034-1382426

Almazari, I., Park, J. M., Park, S. A., Suh, J. Y., Na, H. K., Cha, Y. N., et al. (2012). Guggulsterone induces heme oxygenase-1 expression through activation of Nrf2 in human mammary epithelial cells: PTEN as a putative target. Carcinogenesis 33, 368-376. doi: 10.1093/carcin/bgr259

Ammon, H. P. (2016). Boswellic acids and their role in chronic inflammatory diseases. Adv. Exp. Med. Biol. 928, 291-327. doi: 10.1007/978-3-319-41334-1_13

Ammon, H. P., Safayhi, H., Mack, T., and Sabieraj, J. (1993). Mechanism of antiinflammatory actions of curcumine and boswellic acids. J. Ethnopharmacol.38, 113-119. doi: 10.1016/0378-8741(93)90005-P

An, M. J., Cheon, J. H., Kim, S. W., Kim, E. S., Kim, T. I., and Kim, W. H. (2009). Guggulsterone induces apoptosis in colon cancer cells and inhibits tumor growth in murine colorectal cancer xenografts. Cancer Lett. 279, 93-100. doi: 10.1016/j.canlet.2009.01.026

Arkalgud Rangaswamy, P., Sultana, A., Rahman, K., and Nagapattinam, S. (2014). Efficacy of Boswellia serrata L. and Cyperus scariosus L. plus pelvic floor muscle training in stress incontinence in women of reproductive age. Complement. Ther. Clin. Pract. 20, 230-236. doi: 10.1016/j.ctcp.2014.08.003

Arora, R. B., Kapoor, V., Gupta, S. K., and Sharma, R. C. (1971). Isolation of a crystalline steroidal compound from C. mukul and its anti-inflammatory activity. Indian J. Exp. Biol. 9, 403-404.

Arora, R. B., Taneja, V., Sharma, R. C., and Gupta, S. K. (1972). Anti-inflammatory studies on a crystalline steroid isolated from C. mukul. Indian J. Med. Res. 60, 929-931.

Baldwa, V. S., Bhasin, V., Ranka, P. C., and Mathur, K. M. (1981). Effects of C. mukul (Guggul) in experimentally induced hyperlipemia and atherosclerosis. J. Assoc. Phys. India 29, 13-17.

Banik, K., Harsha, C., Bordoloi, D., Lalduhsaki Sailo, B., Sethi, G., Leong, H. C., et al. (2018). Therapeutic potential of gambogic acid, a caged xanthone, to target cancer. Cancer Lett. 416, 75-86. doi: 10.1016/j.canlet.2017.12.014

Barrett, T. Q., Kristiansen, L. H., and Ovesen, T. (2003). NF-kappaB in cultivated middle ear epithelium Int. J. Pediatr. Otorhinolaryngol. 67, 895-903. doi: 10.1016/S0165-5876(03)00137-X

Batra, S., Srivastava, S., Singh, K., Chander, R., Khanna, A. K., and Bhaduri, A. P. (2000). Syntheses and biological evaluation of 3- substituted amino-1-aryl6-hydroxy- hex-2-ene-1-ones as antioxidant and hypolipidemic agents. Bioorg. Med. Chem. 8, 2195-2209. doi: 10.1016/S0968-0896(00)00159-0

Beg, M., Singhal, K. C., and Afzaal, S. (1996). A study of effect of guggulsterone on hyperlipidemia of secondary glomerulopathy. Indian J. Physiol. Pharmacol. 40, 237-240.

Bhushan, S., Kumar, A., Malik, F., Andotra, S. S., Sethi, V. K., Kaur, I. P., et al. (2007). A triterpenediol from B. serrata induces apoptosis through both the intrinsic and extrinsic apoptotic pathways in human leukemia HL-60 cells. Apoptosis 12, 1911-1926. doi: 10.1007/s10495-007-0105-5

Bordoloi, D., Roy, N. K., Monisha, J., Padmavathi, G., and Kunnumakkara, A. B. (2016). Multi-targeted agents in cancer cell chemosensitization: what we learnt from curcumin thus far. Recent Pat. Anticancer. Drug Discov. 11, 67-97. doi: $10.2174 / 1574892810666151020101706$

Büchele, B., Zugmaier, W., and Simmet, T. (2003). Analysis of pentacyclic triterpenic acids from frankincense gum resins and related phytopharmaceuticals by high-performance liquid chromatography. Identification of lupeolic acid, a novel pentacyclic triterpene. J. Chromatogr. B. 791, 21-30. doi: 10.1016/S1570-0232(03)00160-0

Büchele, B., Zugmaier, W., Estrada, A., Genze, F., Syrovets, T., Paetz, C., et al. (2006). Characterization of 3alpha-acetyl-11-keto-alpha-boswellic acid, a pentacyclic triterpenoid inducing apoptosis in vitro and in vivo. Planta Med.72, 1285-1289. doi: 10.1055/s-2006-951680

Burris, T. P., Montrose, C., Houck, K. A., Osborne, H. E., Bocchinfuso, W. P., Yaden, B. C., et al. (2005). The hypolipidemic natural product guggulsterone is a promiscuous steroid receptor ligand. Mol. Pharmacol. 67, 948-954. doi: $10.1124 / \mathrm{mol} .104 .007054$

Chander, R., Rizvi, F., Khanna, A. K., and Pratap, R. (2003). Cardioprotective activity of synthetic guggulsterone ( $\mathrm{E}$ and Zisomers) in isoproterenol induced myocardial ischemia in rats: a comparative study. Indian J. Clin. Biochem. 18, 71-79. doi: 10.1007/BF02867370

Chashoo, G., Singh, S. K., Sharma, P. R., Mondhe, D. M., Hamid, A., Saxena, A., et al. (2011). A propionyloxy derivative of 11-keto- $\beta$-boswellic acid induces apoptosis in HL-60 cells mediated through topoisomerase I \& II inhibition. Chem. Biol. Interact. 189, 60-71. doi: 10.1016/j.cbi.2010.10.017

Chen, Z., Huang, C., and Ding, W. (2016). Z-guggulsterone improves the scopolamine-induced memory impairments through enhancement of the BDNF signal in C57BL/6J mice. Neurochem. Res. 41, 3322-3332. doi: 10.1007/s11064-016-2064-0

Cheon, J. H., Kim, J. S., Kim, J. M., Kim, N., Jung, H. C., and Song, I. S. (2006). Plant sterol guggulsterone inhibits nuclear factor-kappaB signaling in intestinal epithelial cells by blocking IkappaB kinase and ameliorates acute murine colitis. Inflamm. Bowel Dis. 12, 1152-1161. doi: 10.1097/01.mib.0000235830.94057.c6

Chilelli, N. C., Ragazzi, E., Valentini, R., Cosma, C., Ferraresso, S., Lapolla, A., and Sartore, G. (2016). Curcumin and Boswellia serrata modulate the glyco-oxidative status and lipo-oxidation in master athletes. Nutrients 8:E745. doi: 10.3390/nu8110745

Chopra, A., Saluja, M., Tillu, G., Sarmukkaddam, S., Venugopalan, A., Narsimulu, G., et al. (2013). Ayurvedic medicine offers a good alternative to glucosamine and celecoxib in the treatment of symptomatic knee osteoarthritis: a randomized, double-blind, controlled equivalence drug trial. Rheumatology 52, 1408-1417. doi: 10.1093/rheumatology/kes414

Choudhuri, R., Degraff, W., Gamson, J., Mitchell, J. B., and Cook, J. A. (2011). Guggulsterone-mediated enhancement of radiosensitivity in human tumor cell lines. Front. Oncol. 1:19. doi: 10.3389/fonc.2011.00019

Cuaz-Pérolin, C., Billiet, L., Baugé, E., Copin, C., Scott-Algara, D., Genze, F., et al. (2008). Antiinflammatory and antiatherogenic effects of the NF-kappaB inhibitor acetyl-11-keto-beta-boswellic acid in LPSchallenged ApoE-/- mice. Arterioscler. Thromb. Vasc. Biol. 28, 272-277. doi: 10.1161/ATVBAHA.107.155606

Cui, J., Huang, L., Zhao, A., Lew, J. L., Yu, J., Sahoo, S., et al. (2003). Guggulsterone is a farnesoid $\mathrm{X}$ receptor antagonist in coactivator association assays but acts to enhance transcription of bile salt export pump. J. Biol. Chem. 278, 10214-10220. doi: 10.1074/jbc.M209323200

Dalvi, S. S., Nayak, V. K., Pohujani, S. M., Desai, N. K., Kshirsagar, N. A., and Gupta, K. C. (1994). Effect of gugulipid on bioavailability of diltiazem and propranolol. J. Assoc. Physicians India 42, 454-455.

De Gottardi, A., Dumonceau, J. M., Bruttin, F., Vonlaufen, A., Morard, I., Spahr, L., et al. (2006). Expression of the bile acid receptor FXR in Barrett's esophagus and enhancement of apoptosis by guggulsterone in vitro. Mol. Cancer 5:48. doi: $10.1186 / 1476-4598-5-48$

Deng, R. (2007). Therapeutic effects of guggul and its constituent guggulsterone: cardiovascular benefits. Cardiovasc. Drug Rev. 25, 375-390. doi: 10.1111/j.1527-3466.2007.00023.x

Dhaneshwar, S., Dipmala, P., Abhay, H., and Prashant, B. (2013). Diseasemodifying effect of anthraquinone prodrug with boswellic acid on collagenaseinduced osteoarthritis in Wistar rats. Inflamm. Allergy Drug Targets 12, 288-295. doi: 10.2174/18715281113129990002

Ding, Y., Chen, M., Wang, M., Li, Y., and Wen, A. (2015). Posttreatment with 11 -Keto- $\beta$-boswellic acid ameliorates cerebral ischemia-reperfusion injury: Nrf2/HO-1 pathway as a potential mechanism. Mol. Neurobiol. 52, 1430-1439. doi: 10.1007/s12035-014-8929-9

Ding, Y., Chen, M., Wang, M., Wang, M., Zhang, T., Park, J., et al (2014). Neuroprotection by acetyl-11-keto- $\beta$-Boswellic acid, in ischemic brain injury involves the Nrf2/HO-1 defense pathway. Sci. Rep. 4:7002. doi: 10.1038/srep07002

Dixit, D., Ghildiyal, R., Anto, N. P., Ghosh, S., Sharma, V., and Sen, E. (2013). Guggulsterone sensitizes glioblastoma cells to Sonic hedgehog inhibitor SANT-1 induced apoptosis in a Ras/NFKB dependent manner. Cancer Lett. 336, 347-358. doi: 10.1016/j.canlet.2013. 03.025

Dixit, V. P., Joshi, S., Sinha, R., Bharvava, S. K., and Varma, M. (1980). Hypolipidemic activity of guggal resin (C. mukul) and garlic (Alium sativum 
linn.) in dogs (Canis familiaris) and monkeys (Presbytis entellus entellus Dufresne). Biochem. Exp. Biol. 16, 421-424.

Du, Z., Liu, Z., Ning, Z., Liu, Y., Song, Z., Wang, C., et al. (2015). Prospects of boswellic acids as potential pharmaceutics. Planta Med. 81, 259-271. doi: $10.1055 / \mathrm{s}-0034-1396313$

Fan, A. Y., Lao, L., Zhang, R. X., Zhou, A. N., Wang, L. B., Moudgil, K. D., et al. (2005). Effects of an acetone extract of B. carterii Birdw. (Burseraceae) gum resin on adjuvant-induced arthritis in lewis rats. J. Ethnopharmacol. 101, 104-109. doi: 10.1016/j.jep.2005.03.033

Ferrara, T., De Vincentiis, G., and Di Pierro, F. (2015). Functional study on Boswellia phytosome as complementary intervention in asthmatic patients. Eur. Rev. Med. Pharmacol. Sci. 19, 3757-3762.

Francis, J. A., Raja, S. N., and Nair, M. G. (2004). Bioactive terpenoids and guggulsteroids from $C$. mukul gum resin of potential anti-inflammatory interest. Chem. Biodiversity 1, 1842-1853. doi: 10.1002/cbdv.200490138

Frank, M. B., Yang, Q., Osban, J., Azzarello, J. T., Saban, M. R., Saban, R., et al. (2009). Frankincense oil derived from Boswellia carteri induces tumor cell specific cytotoxicity. BMC Complement. Altern. Med. 9:6. doi: 10.1186/1472-6882-9-6

Gerhardt, H., Seifert, F., Buvari, P., Vogelsang, H., and Repges, R. (2001). Therapy of active Crohn disease with Boswellia serrata extract H 15. Z. Gastroenterol. 39, 11-17. doi: 10.1055/s-2001-10708

Glaser, T., Winter, S., Groscurth, P., Safayhi, H., Sailer, E. R., Ammon, H. P., et al. (1999). Boswellic acids and malignant glioma: induction of apoptosis but no modulation of drug sensitivity. Br. J. Cancer. 80, 756-765. doi: $10.1038 /$ sj.bjc.6690419

Guan, B., Hoque, A., and Xu, X. (2014). Amiloride and guggulsterone suppression of esophageal cancer cell growth in vitro and in nude mouse xenografts. Front. Biol. 9, 75-81. doi: 10.1007/s11515-014-1289-z

Guan, B., Li, H., Yang, Z., Hoque, A., and Xu, X. (2013). Inhibition of farnesoid $\mathrm{X}$ receptor controls esophageal cancer cell growth in vitro and in nude mouse xenografts. Cancer 119, 1321-1329. doi: 10.1002/cncr.27910

Gupta, I., Gupta, V., Parihar, A., Gupta, S., Lüdtke, R., Safayhi, H., et al. (1998). Effects of $B$. serrata gum resin in patients with bronchial asthma: results of a double-blind, placebo-controlled, 6-week clinical study. Eur. J. Med. Res. 3, 511-514

Gupta, I., Parihar, A., Malhotra, P., Gupta, S., Lüdtke, R., Safayhi, H., et al. (2001). Effects of gum resin of $B$. serrata in patients with chronic colitis. Planta Med. 67, 391-395. doi: 10.1055/s-2001-15802

Gupta, I., Parihar, A., Malhotra, P., Singh, G. B., Lüdtke, R., Safayhi, H., et al. (1997). Effects of B. serrata gum resin in patients with ulcerative colitis. Eur. J. Med. Res. 2, 37-43.

Hanus, L. O., Rezanka, T., Dembitsky, V. M., and Moussaieff, A. (2005). Myrrhcommiphora chemistry. Biomed. Papers 149, 3-28. doi: 10.5507/bp.2005.001

Harsha, C., Banik, K., Bordoloi, D., and Kunnumakkara, A. B. (2017). Antiulcer properties of fruits and vegetables: a mechanism based perspective. Food Chem. Toxicol. 108, 104-119. doi: 10.1016/j.fct.2017.07.023

Hazra, A. K., Sur, T. K., Chakraborty, B., and Seal, T. (2018). HPLC analysis of phenolic acids and antioxidant activity of some classical ayurvedic guggulu formulations. Int. J. Res. Ayurveda Pharm. 9, 112-117. doi: 10.7897/2277-4343.09122

Hoernlein, R. F., Orlikowsky, T. H., Zehrer, C., Niethammer, D., Sailer, E. R., Simmet, T., et al. (1999). Acetyl-11-keto-beta-boswellic acid induces apoptosis in HL-60 and CCRF-CEM cells and inhibits topoisomerase I. J. Pharmacol. Exp. Ther. 288, 613-619.

Holtmeier, W., Zeuzem, S., Preiss, J., Kruis, W., Böhm, S., Maaser, C., et al. (2011). Randomized, placebo-controlled, double- blind trial of B. serrata in maintaining remission of Crohn's disease: good safety profile but lack of efficacy. Inflamm. Bowel Dis. 17, 573-582. doi: 10.1002/ibd.21345

Hostanska, K., Daum, G., and Saller, R. (2002). Cytostatic and apoptosis-inducing activity of boswellic acids toward malignant cell lines in vitro. Anticancer Res. $22,2853-2862$

Huang, C., Wang, J., Lu, X., Hu, W., Wu, F., Jiang, B., et al. (2016). Z-guggulsterone negatively controls microglia-mediated neuroinflammation via blocking ІкB$\alpha$-NF-kB signals. Neurosci. Lett. 619, 34-42. doi: 10.1016/j.neulet.2016.02.021

Huang, M. T., Badmaev, V., Ding, Y., Liu, Y., Xie, J. G., and Ho, C. T. (2000). Anti-tumor and anti-carcinogenic activities of triterpenoid, beta-boswellic acid. Biofactors 13, 225-230. doi: 10.1002/biof.5520130135
Ichikawa, H., and Aggarwal, B. B. (2006). Guggulsterone inhibits osteoclastogenesis induced by receptor activator of nuclear factor-kappaB ligand and by tumor cells by suppressing nuclear factor-kappaB activation. Clin. Cancer Res. 12, 662-668. doi: 10.1158/1078-0432.CCR-05-1749

Jiang, G., Xiao, X., Zeng, Y., Nagabhushanam, K., Majeed, M., and Xiao, D. (2013). Targeting beta-catenin signaling to induce apoptosis in human breast cancer cells by z-guggulsterone and Gugulipid extract of Ayurvedic medicine plant Commiphora mukul. BMC Complement. Altern. Med. 13:203. doi: 10.1186/1472-6882-13-203

Jing, Y., Nakajo, S., Xia, L., Nakaya, K., Fang, Q., Waxman, S., et al. (1999). Boswellic acid acetate induces differentiation and apoptosis in leukemia cell lines. Leuk. Res. 23, 43-50. doi: 10.1016/S0145-2126(98)00096-4

Kalariya, N. M., Shoeb, M., Reddy, A. B., Zhang, M., Van Kuijk, F. J., and Ramana, K. V. (2010). Prevention of endotoxin-induced uveitis in rats by plant sterol guggulsterone. Invest. Ophthalmol. Vis. Sci. 51, 5105-5113. doi: $10.1167 /$ iovs. $09-4873$

Kang, S. J., Kim, J. M., Koh, S. J., Kim, S. H., Im, J. P., Jung, H. C., et al. (2013). The guggulsterone derivative GG-52 inhibits NF- $\mathrm{kB}$ signaling in bone marrowderived dendritic cells and attenuates colitis in IL-10 knockout mice. Life Sci. 92, 1064-1071. doi: 10.1016/j.lfs.2013.04.003

Kaul, S., and Kapoor, N. K. (1989). Reversal of changes of lipid peroxide, xanthine oxidase and superoxide dismutase by cardio-protective drugs in isoproterenol induced myocardial necrosis in rats. Indian. J. Exp. Biol. 27, 625-627.

Khan, M. K., Ansari, I. A., and Khan, M. S. (2013), Dietary phytochemicals as potent chemotherapeutic agents against breast cancer: inhibition of NF-kappaB pathway via molecular interactions in rel homology domain of its precursor protein p105. Pharmacogn. Mag. 9, 51-57. doi: 10.4103/0973-1296.108140

Khan, S., Kaur, R., Shah, B. A., Malik, F., Kumar, A., Bhushan, S., et al. (2012). A novel cyano derivative of 11-keto- $\beta$-boswellic acid causes apoptotic death by disrupting PI3K/AKT/Hsp-90 cascade, mitochondrial integrity, and other cell survival signaling events in HL-60 cells. Mol. Carcinog. 51, 679-695. doi: $10.1002 / \mathrm{mc} .20821$

Khanna, D. S., Agarwal, O. P., Gupta, S. K., and Arora, R. B. (1969). A biochemical approach to anti-atherosclerotic action of Commiphora-mukul: an Indian indigenous drug in Indian domestic pigs (Sus scrofa). Indian J. Med. Res. 57, 900-906.

Khosravi Samani, M., Mahmoodian, H., Moghadamnia, A., Poorsattar Bejeh Mir, A., and Chitsazan, M. (2011). The effect of Frankincense in the treatment of moderate plaque-induced gingivitis: a double blinded randomized clinical trial. Daru 19, 288-294.

Kim, B. H., Yoon, J. H., Yang, J. I., Myung, S. J., Lee, J. H., Jung, E. U., et al. (2013). Guggulsterone attenuates activation and survival of hepatic stellate cell by inhibiting nuclear factor kappa B activation and inducing apoptosis. $J$. Gastroenterol. Hepatol. 28, 1859-1868. doi: 10.1111/jgh.12314

Kim, D. G., Bae, G. S., Choi, S. B., Jo, I. J., Shin, J. Y., Lee, S. K., et al. (2015). Guggulsterone attenuates cerulein-induced acute pancreatitis via inhibition of ERK and JNK activation. Int. Immunopharmacol. 26, 194-202. doi: 10.1016/j.intimp.2015.03.030

Kim, D. G., Bae, G. S., Jo, I. J., Choi, S. B., Kim, M. J., Jeong, J. H., et al. (2016). Guggulsterone attenuated lipopolysaccharideinduced inflammatory responses in mouse inner medullary collecting duct-3 cells. Inflammation 39, 87-95. doi: 10.1007/s10753-0150226-x

Kim, E. S., Hong, S. Y., Lee, H. K., Kim, S. W., An, M. J., Kim, T. I., et al. (2008). Guggulsterone inhibits angiogenesis by blocking STAT3 and VEGF expression in colon cancer cells. Oncol. Rep. 20, 1321-1327. doi: 10.3892/or_00000147

Kim, J. M., Kang, H. W., Cha, M. Y., Yoo, D., Kim, N., Kim, I. K., et al. (2010). Novel guggulsterone derivative GG-52 inhibits NF-kappaB signaling in intestinal epithelial cells and attenuates acute murine colitis. Lab. Invest. 90, 1004-1015. doi: 10.1038/labinvest.2010.54

Kim, N., Park, J. M., Lee, S. H., Kim, B. H., Son, J. H., Ryu, J. K., et al. (2017). Effect of combinatory treatment with resveratrol and guggulsterone on mild acute pancreatitis in mice. Pancreas 46, 366-371. doi: 10.1097/MPA.0000000000000763

Kimmatkar, N., Thawani, V., Hingorani, L., and Khiyani, R. (2003). Efficacy and tolerability of $B$. serrata extract in treatment of osteoarthritis of kneea randomized double blind placebo controlled trial. Phytomedicine 10, 3-7. doi: $10.1078 / 094471103321648593$ 
Kimura, I., Yoshikawa, M., Kobayashi, S., Sugihara, Y., Suzuki, M., Oominami, H., et al. (2001). New triterpenes, myrrhanol A and myrrhanone A, from guggul-gum resins, and their potent antiinflammatory effect on adjuvantinduced air-pouch granuloma of mice. Bioorg. Med. Chem. Lett. 11, 985-989. doi: 10.1016/S0960-894X(01)00111-1

Kinne, R. W., Stuhlmüller, B., and Burmester, G. R. (2007). Cells of the synovium in rheumatoid arthritis Macrophages. Arthritis Res. Ther. 9:224. doi: 10.1186/ar2333

Kirste, S., Treier, M., Wehrle, S. J., Becker, G., Abdel-Tawab, M., Gerbeth, K., et al.(2011). Boswellia serrata acts on cerebral edema in patients irradiated for brain tumors: a prospective, randomized, placebo-controlled, double-blind pilot trial. Cancer 117, 3788-3795. doi: 10.1002/cncr.25945

Kizhakkedath, R. (2013).Clinical evaluation of a formulation containing Curcuma longa and Boswellia serrata extracts in the management of knee osteoarthritis. Mol. Med. Rep. 8, 1542-1548. doi: 10.3892/mmr.2013.1661

Kong, J. N., He, Q., Wang, G., Dasgupta, S., Dinkins, M. B., Zhu, G., et al. (2015). Guggulsterone and bexarotene induce secretion of exosome-associated breast cancer resistance protein and reduce doxorubicin resistance in MDA-MB-231 cells. Int. J. Cancer 137, 1610-1620. doi: 10.1002/ijc.29542

Koo, J. H., Rhee, K. S., Koh, H. W., Jang, H. Y., Park, B. H., and Park, J. W. (2012). Guggulsterone inhibits melanogenesis in B16 murine melanoma cells by downregulating tyrosinase expression. Int. J. Mol. Med. 30, 974-978. doi: 10.3892/ijmm.2012.1057

Krieglstein, C. F., Anthoni, C., Rijcken, E. J., Laukötter, M., Spiegel, H. U., Boden, S. E., et al. (2001). Acetyl-11-keto-beta-boswellic acid, a constituent of a herbal medicine from Boswellia serrata resin, attenuates experimental ileitis. Int. J. Colorectal Dis. 16, 88-95. doi: 10.1007/s003840100292

Kulkarni, R. R., Patki, P. S., Jog, V. P., Gandage, S. G., and Patwardhan, B. (1991). Treatment of osteoarthritis with a herbomineral formulation: a doubleblind, placebo-controlled, cross-over study. J. Ethnopharmacol. 33, 91-95. doi: 10.1016/0378-8741(91)90167-C

Kunnumakkara, A. B., Bordoloi, D., Harsha, C., Banik, K., Gupta, S. C., and Aggarwal, B. B. (2017). Curcumin mediates anticancer effects by modulating multiple cell signaling pathways. Clin. Sci. 131, 1781-1799. doi: 10.1042/CS20160935

Kunnumakkara, A. B., Nair, A. S., Sung, B., Pandey, M. K., and Aggarwal, B. B. (2009). Boswellic acid blocks signal transducers and activators of transcription 3 signaling, proliferation, and survival of multiple myeloma via the protein tyrosine phosphatase SHP-1. Mol. Cancer Res. 7, 118-128. doi: 10.1158/1541-7786.MCR-08-0154

Kunnumakkara, A. B., Sailo, B. L., Banik, K., Harsha, C., Prasad, S., Gupta, S. C., et al. (2018). Chronic diseases, inflammation, and spices: how are they linked? J. Transl. Med. 16:14. doi: 10.1186/s12967-018-1381-2

Lata, S., Saxena, K. K., Bhasin, V., Saxena, R. S., Kumar, A., and Srivastava, V. K. (1991). Beneficial effects of Allium sativum, Allium cepa and C. mukul on experimental hyperlipidemia and atherosclerosis - a comparative evaluation. J. Postgrad. Med. 37, 132-135.

Lee, D., Kim, T., Kim, K. H., Ham, J., Jang, T. S., Kang, K. S., et al. (2017). Evaluation of guggulsterone derivatives as novel kidney cell protective agents against cisplatin-induced nephrotoxicity. Bioorg. Med. Chem. Lett. 27, 3156-3161. doi: 10.1016/j.bmcl.2017.05.033

Lee, Y. R., Lee, J. H., Noh, E. M., Kim, E. K., Song, M. Y., Jung, W. S., et al. (2008). Guggulsterone blocks IL-1beta-mediated inflammatory responses by suppressing NF-kappaB activation in fibroblast-like synoviocytes. Life Sci. 82, 1203-1209. doi: 10.1016/j.lfs.2008.04.006

Leeman-Neill, R. J., Wheeler, S. E., Singh, S. V., Thomas, S. M., Seethala, R. R., Neill, D. B., et al. (2009). Guggulsterone enhances head and neck cancer therapies via inhibition of signal transducer and activator of transcription-3. Carcinogenesis 30, 1848-1856. doi: 10.1093/carcin/bgp211

Li, C., Zang, Y., Sen, M., Leeman-Neill, R. J., Man, D. S., Grandis, J. R., et al. (2009). Bortezomib up-regulates activated signal transducer and activator of transcription-3 and synergizes with inhibitors of signal transducer and activator of transcription 3 to promote head and neck squamous cell carcinoma cell death. Mol. Cancer Ther. 8, 2211-2220. doi: 10.1158/1535-7163.MCT-09-0327

Liu, F. G., Hu, W. F., Wang, J. L., Wang, P., Gong, Y., Tong, L. J., et al. (2017). Zguggulsterone produces antidepressant-like effects in mice through activation of the BDNF signaling pathway. Int. J. Neuropsychopharmacol. 20, 485-497. doi: $10.1093 /$ ijnp/pyx009
Liu, H. P., Gao, Z. H., Cui, S. X., Wang, Y., Li, B. Y., Lou, H. X., et al. (2013). Chemoprevention of intestinal adenomatous polyposis by acetyl-11keto-beta-boswellic acid in APC(Min/+) mice. Int. J. Cancer 132, 2667-2681. doi: 10.1002/ijc.27929

Liu, J. J., Huang, B., and Hooi, S. C. (2006). Acetyl-keto-beta-boswellic acid inhibits cellular proliferation through a p21-dependent pathway in colon cancer cells. Br. J. Pharmacol. 148, 1099-1107. doi: 10.1038/sj.bjp.0706817

Liu, J. J., Nilsson, A., Oredsson, S., Badmaev, V., and Duan, R. D. (2002a). Ketoand acetyl-keto-boswellic acids inhibit proliferation and induce apoptosis in Hep G2 cells via a caspase-8 dependent pathway. Int. J. Mol. Med. 10, 501-505. doi: 10.3892/ijmm.10.4.501

Liu, J. J., Nilsson, A., Oredsson, S., Badmaev, V., Zhao, W. Z., and Duan, R. D. (2002b). Boswellic acids trigger apoptosis via a pathway dependent on caspase-8 activation but independent on Fas/Fas ligand interaction in colon cancer HT-29 cells. Carcinogenesis 23, 2087-2093. doi: 10.1093/carcin/23.12.2087

Liu, Z., Liu, X., Sang, L., Liu, H., Xu, Q., and Liu, Z. (2015). Boswellic acid attenuates asthma phenotypes by downregulation of GATA3 via pSTAT6 inhibition in a murine model of asthma. Int. J. Clin. Exp. Pathol. 8, 236-243.

Lu, M., Xia, L., Hua, H., and Jing, Y. (2008). Acetyl-keto-beta-boswellic acid induces apoptosis through a death receptor 5-mediated pathway in prostate cancer cells. Cancer Res. 68, 1180-1186. doi: 10.1158/0008-5472.CAN-07-2978

Macha, M. A., Matta, A., Chauhan, S. S., Siu, K. W., and Ralhan, R. (2011a). Guggulsterone (GS) inhibits smokeless tobacco and nicotine-induced NF-кB and STAT3 pathways in head and neck cancer cells. Carcinogenesis 32, 368-380. doi: 10.1093/carcin/bgq278

Macha, M. A., Matta, A., Chauhan, S., Siu, K. M., and Ralhan, R. (2010). 14-3-3 zeta is a molecular target in guggulsterone induced apoptosis in head and neck cancer cells. BMC Cancer 10:655. doi: 10.1186/1471-2407-10-655

Macha, M. A., Matta, A., Chauhan, S., Siu, K. M., and Ralhan, R. (2011b). Guggulsterone targets smokeless tobacco induced PI3K/Akt pathway in head and neck cancer cells. PLoS ONE 6:e14728. doi: 10.1371/journal.pone.0014728

Macha, M. A., Rachagani, S., Gupta, S., Pai, P., Ponnusamy, M. P., Batra, S. K., et al. (2013). Guggulsterone decreases proliferation and metastatic behavior of pancreatic cancer cells by modulating JAK/STAT and Src/FAK signaling. Cancer Lett. 341, 166-177. doi: 10.1016/j.canlet.2013.07.037

Magin, P. J., Adams, J., Pond, C. D., and Smith, W. (2006). Topical and oral CAM in acne: a review of the empirical evidence and a consideration of its context. Complement. Ther. Med. 14, 62-76. doi: 10.1016/j.ctim.2005.10.007

Mahesh, B. U., Shrivastava, S., Pragada, R. R., Naidu, V. G., and Sistla, R. (2014). Antioxidant and hepatoprotective effects of Boswellia ovalifoliolata bark extracts. Chin. J. Nat. Med. 12, 663-671. doi: 10.1016/S1875-5364(14)60101-1

Massoud, A., El Sisi, S., Salama, O., and Massoud, A. (2001). Preliminary study of therapeutic efficacy of a new fasciolicidal drug derived from Commiphora molmol (myrrh). Am. J. Trop. Med. Hyg. 65, 96-99. doi: 10.4269/ajtmh.2001.65.96

Mencarelli, A., Renga, B., Palladino, G., Distrutti, E., and Fiorucci, S. (2009). The plant sterol guggulsterone attenuates inflammation and immune dysfunction in murine models of inflammatory bowel disease. Biochem. Pharmacol. 78, 1214-1223. doi: 10.1016/j.bcp.2009.06.026

Meselhy, M. R. (2003). Inhibition of LPS-induced NO production by the oleogum resin of Commiphora wightii and its constituents. Phytochemistry 62, 213-218. doi: 10.1016/S0031-9422(02)00388-6

Meyer, U., Costantino, G., Macchiarulo, A., and Pellicciari, R. (2005). Is antagonism of E/Z-guggulsterone at the farnesoid $\mathrm{X}$ receptor mediated by a noncanonical binding site? A molecular modeling study. J. Med. Chem. 48, 6948-6955. doi: 10.1021/jm0505056

Moon, D. O., Park, S. Y., Choi, Y. H., Ahn, J. S., and Kim, G. Y. (2011). Guggulsterone sensitizes hepatoma cells to TRAIL-induced apoptosis through the induction of CHOP-dependent DR5: involvement of ROS-dependent ER-stress. Biochem. Pharmacol. 82, 1641-1650. doi: 10.1016/j.bcp.2011. 08.019

Morad, S. A., Schmid, M., Buchele, B., Siehl, H. U., El Gafaary, M., Lunov, O., et al. (2013). A novel semisynthetic inhibitor of the FRB domain of mammalian target of rapamycin blocks proliferation and triggers apoptosis in chemoresistant prostate cancer cells. Mol. Pharmacol. 83, 531-541. doi: $10.1124 / \mathrm{mol} .112 .081349$

Moreillon, J. J., Bowden, R. G., Deike, E., Griggs, J., Wilson, R., Shelmadine, B., et al. (2013). The use of an anti-inflammatory supplement in patients 
with chronic kidney disease. J. Complement Integr. Med. 10, 143-152. doi: 10.1515/jcim-2012-0011

Nabekura, T., Yamaki, T., Ueno, K., and Kitagawa, S. (2008). Inhibition of P-glycoprotein and multidrug resistance protein 1 by dietary phytochemicals. Cancer Chemother. Pharmacol. 62, 867-873. doi: 10.1007/s00280-007-0676-4

Nityanand, S., Srivastava, J. S., and Asthana, O. P. (1989). Clinical trials with gugulipid. A new hypolipidaemic agent. J. Assoc. Physicians India 37, 323-328.

Nohr, L. A., Rasmussen, L. B., and Straand, J. (2009). Resin from the mukul myrrh tree, guggul, can it be used for treating hypercholesterolemia? A randomized, controlled study. Complement. Ther. Med. 17, 16-22. doi: 10.1016/j.ctim.2008.07.001

Ojha, S., Bhatia, J., Arora, S., Golechha, M., Kumari, S., and Arya, D. S. (2011). Cardioprotective effects of C. mukul against isoprenaline-induced cardiotoxicity: a biochemical and histopathological evaluation. J. Environ. Biol. $32,731-738$

Ovesen, T., and Ledet, T. (1992). Bacteria and endotoxin in middle ear fluid and the course of secretory otitis media. Clin. Otolaryngol. Allied Sci. 17, 531-534. doi: 10.1111/j.1365-2273.1992.tb01713.x

Owsley, E., and Chiang, J. Y. (2003). Guggulsterone antagonizes farnesoid X receptor induction of bile salt export pump but activates pregnane $\mathrm{X}$ receptor to inhibit cholesterol 7alpha-hydroxylase gene. Biochem. Biophys. Res. Commun. 304, 191-195. doi: 10.1016/S0006-291X(03)00551-5

Panda, S., and Kar, A. (2005). Guggulu (C. mukul) potentially ameliorates hypothyroidism in female mice. Phytother Res. 19, 78-80. doi: 10.1002/ptr.1602

Pang, X., Yi, Z., Zhang, X., Sung, B., Qu, W., Lian, X., et al. (2009). Acetyl-11-ketobeta-boswellic acid inhibits prostate tumor growth by suppressing vascular endothelial growth factor receptor 2-mediated angiogenesis. Cancer Res. 69, 5893-5900. doi: 10.1158/0008-5472.CAN-09-0755

Park, B., Prasad, S., Yadav, V., Sung, B., and Aggarwal, B. B. (2011a). Boswellic acid suppresses growth and metastasis of human pancreatic tumors in an orthotopic nude mouse model through modulation of multiple targets. PLoS ONE 6:e26943. doi: 10.1371/journal.pone.0026943

Park, B., Sung, B., Yadav, V. R., Cho, S. G., Liu, M., and Aggarwal, B. B. (2011b). Acetyl-11-keto- $\beta$-boswellic acid suppresses invasion of pancreatic cancer cells through the downregulation of CXCR4 chemokine receptor expression. Int. J. Cancer 129, 23-33. doi: 10.1002/ijc.25966

Park, Y. S., Lee, J. H., Bondar, J., Harwalkar, J. A., Safayhi, H., and Golubic, M. (2002a). Cytotoxic action of acetyl-11-keto-beta-boswellic acid (AKBA) on meningioma cells. Planta Med. 68, 397-401. doi: 10.1055/s-2002-32090

Park, Y. S., Lee, J. H., Harwalkar, J. A., Bondar, J., Safayhi, H., and Golubic, M. (2002b). Acetyl-11-keto-beta-boswellic acid (AKBA) is cytotoxic for meningioma cells and inhibits phosphorylation of the extracellularsignal regulated kinase 1 and 2. Adv. Exp. Med. Biol. 507, 387-393. doi: 10.1007/978-1-4615-0193-0_60

Pasta, V., Dinicola, S., Giuliani, A., Harrath, A. H., Alwasel, S. H., Tartaglia, F., et al. (2016). A randomized trial of Boswellia in association with betaine and myoinositol in the management of breast fibroadenomas. Eur. Rev. Med. Pharmacol. Sci. 20, 1860-1865.

Pathania, A. S., Wani, Z. A., Guru, S. K., Kumar, S., Bhushan, S., Korkaya, H., et al. (2015). The anti-angiogenic and cytotoxic effects of the boswellic acid analog BA145 are potentiated by autophagy inhibitors. Mol. Cancer. 14:6. doi: 10.1186/1476-4598-14-6

Patti, A. M., Al-Rasadi, K., Katsiki, N., Banerjee, Y., Nikolic, D., Vanella, L., et al. (2015). Effect of a natural supplement containing Curcuma longa, guggul, and chlorogenic acid in patients with metabolic syndrome. Angiology 66, 856-861. doi: $10.1177 / 0003319714568792$

Prabhavathi, K., Chandra, U. S., Soanker, R., and Rani, P. U. (2014). A randomized, double blind, placebo controlled, cross over study to evaluate the analgesic activity of Boswellia serrata in healthy volunteers using mechanical pain model. Indian J. Pharmacol. 46, 475-479. doi: 10.4103/0253-7613.140570

Qurishi, Y., Hamid, A., Sharma, P. R., Wani, Z. A., Mondhe, D. M., Singh, S. K., et al. (2012). PARP cleavage and perturbance in mitochondrial membrane potential by 3 - $\alpha$-propionyloxy- $\beta$-boswellic acid results in cancer cell death and tumor regression in murine models. Future Oncol. 8, 867-881. doi: $10.2217 /$ fon. 12.68

Qurishi, Y., Hamid, A., Sharma, P. R., Wani, Z. A., Mondhe, D. M., Singh, S. K., et al. (2013). NF-kB down-regulation and PARP cleavage by novel 3 - $\alpha$-butyryloxy- $\beta$-boswellic acid results in cancer cell specific apoptosis and in vivo tumor regression. Anticancer. Agents Med. Chem. 13, 777-790. doi: 10.2174/1871520611313050012

Ravanan, P., Singh, S. K., Rao, G. S., and Kondaiah, P. (2011). Growth inhibitory, apoptotic and anti-inflammatory activities displayed by a novel modified triterpenoid, cyano enone of methyl boswellates. J. Biosci. 36, 297-307. doi: 10.1007/s12038-011-9056-7

Reddy, G. K., and Dhar, S. C. (1987). Effect of a new non-steroidal antiinflammatory agent on lysosomal stability in adjuvant induced arthritis. Ital. J. Biochem. 36, 205-217.

Riva, A., Morazzoni, P., Artariam, C., Allegrinim, P., Meinsm, J., Savio Appendino, G., et al. (2016). A single-dose, randomized, cross-over, two-way, openlabel study for comparing the absorption of boswellic acids and its lecithin formulation. Phytomedicine 23, 1375-1382. doi: 10.1016/j.phymed.2016.07.009

Rizzo, G., Disante, M., Mencarelli, A., Renga, B., Gioiello, A., Pellicciari, R., et al. (2006). The farnesoid $\mathrm{X}$ receptor promotes adipocyte differentiation and regulates adipose cell function in vivo. Mol. Pharmacol. 70, 1164-1173. doi: 10.1124/mol.106.023820

Roy, N. K., Deka, A., Bordoloi, D., Mishra, S., Kumar, A. P., Sethi, G., et al. (2016). The potential role of boswellic acids in cancer prevention and treatment. Cancer Lett. 377, 74-86. doi: 10.1016/j.canlet.2016.04.017

Safayhi, H., Mack, T., Sabieraj, J., Anazodo, M. I., Subramanian, L. R., and Ammon, H. P. (1992). Boswellic acids: novel, specific, nonredox inhibitors of 5-lipoxygenase. J. Pharmacol. Exp. Ther. 261, 1143-1146.

Safayhi, H., Rall, B., Sailer, E. R., and Ammon, H. P. (1997). Inhibition by boswellic acids of human leukocyte elastase. J. Pharmacol. Exp. Ther. 281, 460-463.

Safayhi, H., Sailer, E. R., and Ammon, H. P. (1995). Mechanism of 5lipoxygenase inhibition by acetyl-11-keto-beta-boswellic acid. Mol. Pharmacol. $47,1212-1216$.

Samudio, I., Konopleva, M., Safe, S., McQueen, T., and Andreeff, M. (2005). Guggulsterones induce apoptosis and differentiation in acute myeloid leukemia: identification of isomer-specific antileukemic activities of the pregnadienedione structure. Mol. Cancer Ther. 4, 1982-1992. doi: 10.1158/1535-7163.MCT-05-0247

Sander, O., Herborn, G., and Rau, R. (1998). Is H15 (resin extract of Boswellia serrata, "incense") a useful supplement to established drug therapy of chronic polyarthritis? Results of a double-blind pilot study. Z. Rheumatol. 57, 11-16. doi: $10.1007 / \mathrm{s} 003930050051$

Sarup, P., Bala, S., and Kamboj, S. (2015). Pharmacology and Phytochemistry of Oleo-Gum Resin of Commiphora wightii (Guggulu). Scientifica 2015:138039. doi: $10.1155 / 2015 / 138039$

Satyavati, G. V., Dwarakanath, C., and Tripathi, S. N. (1969). Experimental studies on the hypocholesterolemic effect of C. mukul Engl. (Guggul). Indian J. Med. Res. 57, 1950-1962.

Saxena, G., Singh, S. P., Pal, R., Singh, S., Pratap, R., and Nath, C. (2007). Guggulipid, an extract of Commiphora whighitii with lipid- lowering properties, has protective effects against streptozotocin-induced memory deficits in mice. Pharmacol. Biochem. Behav. 86, 797-805. doi: 10.1016/j.pbb.2007.03.010

Scholtes, C., André, P., Trépo, C., Cornu, C., Remontet, L., Ecochard, R., et al. (2012). Farnesoid X receptor targeting for hepatitis C: study protocol for a proof-of-concept trial. Therapie 67, 423-427. doi: 10.2515/therapie/2012058

Sengupta, K., Alluri, K. V., Satish, A. R., Mishra, S., Golakoti, T., Sarma, K. V., et al. (2008). A double blind, randomized, placebo controlled study of the efficacy and safety of 5-Loxin for treatment of osteoarthritis of the knee. Arthritis Res. Ther. 10:R85. doi: 10.1186/ar2461

Shah, R., Gulati, V., and Palombo, E. A. (2012). Pharmacological properties of guggulsterones, the major active components of gum guggul. Phytother. Res. 26, 1594-1605. doi: 10.1002/ptr.4647

Shao, Y., Ho, C. T., Chin, C. K., Badmaev, V., Ma, W., and Huang, M. T. (1998). Inhibitory activity of boswellic acids from Boswellia serrata against human leukemia HL-60 cells in culture. Planta Med. 64, 328-331. doi: 10.1055/s-2006-957444

Sharma, B., Salunke, R., Srivastava, S., Majumder, C., and Roy, P. (2009). Effects of guggulsterone isolated from C. mukul in high fat diet induced diabetic rats. Food Chem. Toxicol. 47, 2631-2639. doi: 10.1016/j.fct.2009.07.021

Sharma, J. N., and Sharma, J. N. (1977). Comparison of the anti-inflammatory activity of C. mukul (an indigenous drug) with those of phenylbutazone and ibuprofen in experimental arthritis induced by mycobacterial adjuvant. Arzneimittelforschung 27, 1455-1457. 
Sharma, M. L., Bani, S., and Singh, G. B. (1989). Anti-arthritic activity of boswellic acids in bovine serum albumin (BSA)-induced arthritis. Int. J. Immunopharmacol. 11, 647-652. doi: 10.1016/0192-0561(89)90150-1

Sheir, Z., Nasr, A. A., Massoud, A., Salama, O., Badra, G. A., El-Shennawy, H., et al. (2001). A safe, effective, herbal antischistosomal therapy derived from myrrh. Am. J. Trop. Med. Hyg. 65, 700-704. doi: 10.4269/ajtmh.2001.65.700

Shelmadine, B. D., Bowden, R. G., Moreillon, J. J., Cooke, M. B., Yang, P., Deike, E., et al. (2017). A pilot study to examine the effects of an anti-inflammatory supplement on eicosanoid derivatives in patients with chronic kidney disease. J. Altern. Complement. Med. 23, 632-638. doi: 10.1089/acm.2016.0007

Shen, Y., Takahashi, M., Byun, H. M., Link, A., Sharma, N., Balaguer, F., et al. (2012). Boswellic acid induces epigenetic alterations by modulating DNAmethylation in colorectal cancer cells. Cancer Biol. Ther. 13, 542-552. doi: $10.4161 /$ cbt. 19604

Shi, J. J., Jia, X. L., Li, M., Yang, N., Li, Y. P., Zhang, X., et al. (2015). Guggulsterone induces apoptosis of human hepatocellular carcinoma cells through intrinsic mitochondrial pathway. World J. Gastroenterol. 21, 13277-13287. doi: 10.3748/wjg.v21.i47.13277

Shishodia, S., and Aggarwal, B. B. (2004). Guggulsterone inhibits NF-kappaB and IkappaBalpha kinase activation, suppresses expression of anti-apoptotic gene products, and enhances apoptosis. J. Biol. Chem. 279, 47148-47158. doi: 10.1074/jbc.M408093200

Shishodia, S., Azu, N., Rosenzweig, J. A., and Jackson, D. A. (2015). Guggulsterone for chemoprevention of cancer. Curr. Pharm. Des. 22, 294-306. doi: 10.2174/1381612822666151112153117

Shishodia, S., Harikumar, K. B., Dass, S., Ramawat, K. G., and Aggarwal, B. B. (2008). The guggul for chronic diseases: ancient medicine, modern targets. Anticancer Res. 28, 3647-3664.

Shishodia, S., Sethi, G., Ahn, K. S., and Aggarwal, B. B. (2007). Guggulsterone inhibits tumor cell proliferation, induces S-phase arrest, and promotes apoptosis through activation of c-Jun $\mathrm{N}$-terminal kinase, suppression of Akt pathway, and downregulation of antiapoptotic gene products. Biochem. Pharmacol. 74, 118-130. doi: 10.1016/j.bcp.2007.03.026

Siddiqui, M. M., Afaq, S. H., and Asif, M. (1984). Chemical standardization of 'Kundur'(Oleo-Gum-Resin of Boswellia serrata Roxb). Anc. Sci. Life. 4, 48-50.

Sinal, C. J., and Gonzalez, F. J. (2002). Guggulsterone: an old approach to a new problem. Trends Endocrinol. Metab. 13, 275-276. doi: 10.1016/S1043-2760(02)00640-9

Singh, A. K., Prasad, G. C., and Tripathi, S. N. (1982). In vitro studies on thyrogenic effect of C. mukul (guggulu). Anc. Sci. Life. 2, 23-28.

Singh, B. B., Mishra, L. C., Vinjamury, S. P., Aquilina, N., Singh, V. J., and Shepard, N. (2003). The effectiveness of C. mukul for osteoarthritis of the knee: an outcomes study. Altern. Ther. Health Med. 9, 74-79.

Singh, R. B., Niaz, M. A., and Ghosh, S. (1994). Hypolipidemic and antioxidant effects of Commiphora mukul as an adjunct to dietary therapy in patients with hypercholesterolemia. Cardiovasc. Drugs Ther. 8, 659-664. doi: $10.1007 / B F 00877420$

Singh, R. P., Singh, R., Ram, P., and Batliwala, P. G. (1993). Use of Pushkar- Guggul, an indigenous antiischemic combination, in the management of ischemic heart disease. Int. J. Pharmacol. 31, 147-160. doi: $10.3109 / 13880209309082932$

Singh, S. K., Bhusari, S., Singh, R., Saxena, A., Mondhe, D., and Qazi, G. N. (2007). Effect of acetyl 11-keto beta-boswellic acid on metastatic growth factor responsible for angiogenesis. Vascul. Pharmacol. 46, 333-337. doi: 10.1016/j.vph.2006.09.008

Singh, S. V., Choi, S., Zeng, Y., Hahm, E. R., and Xiao, D. (2007). Guggulsteroneinduced apoptosis in human prostate cancer cells is caused by reactive oxygen intermediate dependent activation of c-Jun NH2-terminal kinase. Cancer Res. 67, 7439-7449. doi: 10.1158/0008-5472.CAN-07-0120

Singh, S. V., Zeng, Y., Xiao, D., Vogel, V. G., Nelson, J. B., Dhir, R., et al. (2005). Caspase-dependent apoptosis induction by guggulsterone, a constituent of Ayurvedic medicinal plant Commiphora mukul, in PC-3 human prostate cancer cells is mediated by Bax and Bak. Mol. Cancer Ther. 4, 1747-1754. doi: 10.1158/1535-7163.MCT-05-0223

Singh, S., Khajuria, A., Taneja, S. C., Khajuria, R. K., Singh, J., Johri, R. K., et al. (2008). The gastric ulcer protective effect of boswellic acids, a leukotriene inhibitor from Boswellia serrata, in rats. Phytomedicine 15, 408-415. doi: 10.1016/j.phymed.2008.02.017
Singh, V., Kaul, S., Chander, R., and Kapoor, N. K. (1990). Stimulation of low density lipoprotein receptor activity in liver membrane of guggulsterone treated rats. Pharmacol. Res. 22, 37-44. doi: 10.1016/1043-6618(90)90741-U

Song, J. J., Kwon, S. K., Cho, C. G., Park, S. W., and Chae, S. W. (2010). Guggulsterone suppresses LPS induced inflammation of human middle ear epithelial cells (HMEEC). Int. J. Pediatr. Otorhinolaryngol. 74, 1384-1387. doi: 10.1016/j.ijporl.2010.09.012

Syrovets, T., Buchele, B., Gedig, E., Slupsky, J. R., and Simmet, T. (2000). Acetylboswellic acids are novel catalytic inhibitors of human topoisomerases I and II alpha. Mol. Pharmacol. 58, 71-81. doi: 10.1124/mol.58.1.71

Syrovets, T., Büchele, B., Krauss, C., Laumonnier, Y., and Simmet, T. (2005a). Acetyl-boswellic acids inhibit lipopolysaccharide-mediated TNF-alpha induction in monocytes by direct interaction with I kappa B kinases. $J$. Immunol. 174, 498-506. doi: 10.4049/jimmunol.174.1.498

Syrovets, T., Gschwend, J. E., Büchele, B., Laumonnier, Y., Zugmaier, W., Genze, F., et al. (2005b). Inhibition of IkappaB kinase activity by acetyl-boswellic acids promotes apoptosis in androgen-independent PC-3 prostate cancer cells in vitro and in vivo. J. Biol. Chem. 280, 6170-6180. doi: 10.1074/jbc.M409477200

Szapary, P. O., Wolfe, M. L., Bloedon, L. T., Cucchiara, A. J., DerMarderosian, A. H., Cirigliano, M. D., et al. (2003). Guggulipid for the treatment of hypercholesterolemia: a randomized controlled trial. JAMA 290, 765-772. doi: 10.1001/jama.290.6.765

Takada, Y., Ichikawa, H., Badmaev, V., and Aggarwal, B. B. (2006). Acetyl-11keto-beta-boswellic acid potentiates apoptosis, inhibits invasion, and abolishes osteoclastogenesis by suppressing NF-kappa B and NF-kappa B-regulated gene expression. J. Immunol. 176, 3127-3140. doi: 10.4049/jimmunol.176.5.3127

Takahashi, M., Sung, B., Shen, Y., Hur, K., Link, A., Boland, C. R., et al. (2012). Boswellic acid exerts antitumor effects in colorectal cancer cells by modulating expression of the let-7 and miR-200 microRNA family. Carcinogenesis 33, 2441-2449. doi: 10.1093/carcin/bgs286

Thappa, D. M., and Dogra, J. (1994). Nodulocystic acne: oral gugulipid versus tetracycline. J. Dermatol. 21, 729-731. doi: 10.1111/j.1346-8138.1994.tb03277.x

Togni, S., Maramaldi, G., Bonetta, A., Giacomelli, L., and Di Pierro, F. (2015). Clinical evaluation of safety and efficacy of Boswellia-based cream for prevention of adjuvant radiotherapy skin damage in mammary carcinoma: a randomized placebo controlled trial. Eur. Rev. Med. Pharmacol. Sci. 19, 1338-1344.

Togni, S., Maramaldi, G., Di Pierro, F., and Biondi, M. (2014). A cosmeceutical formulation based on boswellic acids for the treatment of erythematous eczema and psoriasis. Clin. Cosmet. Investig. Dermatol. 7, 321-327. doi: $10.2147 /$ CCID.S69240

Tripathi, S. N., Gupta, M., Sen, S. P., and Udupa, K. N. (1975). Effect of a ketosteroid of Commifora mukul $L$. on hypercholesterolemia and hyperlipidemia induced by neomercazole and cholesterol mixture in chicks. Indian J. Exp. Biol. $13,15-18$.

Tripathi, Y. B. (2009). BHUx: a patented polyherbal formulation to prevent hyperlipidemia and atherosclerosis. Recent Pat. Inflamm. Allergy Drug Discov. 3, 49-57. doi: 10.2174/187221309787158443

Tripathi, Y. B., Malhotra, O. P., and Tripathi, S. N. (1984). Thyroid-stimulating action of Z-guggulsterone obtained from C. mukul. Planta Med. 50, 78-80. doi: 10.1055/s-2007-969626

Urizar, N. L., Liverman, A. B., Dodds, D. T., Silva, F. V., Ordentlich, P., Yan, Y., et al. (2002). A natural product that lowers cholesterol as an antagonist ligand for FXR. Science 296, 1703-1706. doi: 10.1126/science.1072891

Verma, S. K., and Bordia, A. (1988). Effect of Commiphora mukul (gum guggulu) in patients of hyperlipidemia with special reference to HDL-cholesterol. Indian J. Med. Res. 87, 356-360.

von Rhein, C., Weidner, T., Hen,ß, L., Martin, J., Weber, C., Sliva, K., et al. (2016). Curcumin and Boswellia serrata gum resin extract inhibit chikungunya and vesicular stomatitis virus infections in vitro. Antiviral Res. 125, 51-57. doi: 10.1016/j.antiviral.2015.11.007

Vyas, K. Y., Bedarkar, P., Galib, R., and Prajapati, P. K. (2015). Comparative Antihyperlipidaemic activity of Navina (fresh) and Purāna (old) Guggulu. Anc. Sci. Life. 35, 101-109. doi: 10.4103/0257-7941.171672

Wang, Q., Pan, X., Wong, H. H., Wagner, C. A., Lahey, L. J., Robinson, W. H., et al. (2014). Oral and topical boswellic acid attenuates mouse osteoarthritis. Osteoarthr. Cartil. 22, 128-132. doi: 10.1016/j.joca.2013. 10.012 
Wang, R., Wang, Y., Gao, Z., and Qu, X. (2014). The comparative study of acetyl11-keto-beta-boswellic acid (AKBA) and aspirin in the prevention of intestinal adenomatous polyposis in APC(Min/+) mice. Drug Discov. Ther. 8, 25-32. doi: $10.5582 /$ ddt.8.25

Wang, W. C., Uen, Y. H., Chang, M. L., Cheah, K. P., Li, J. S., Yu, W. Y., et al. (2012). Protective effect of guggulsterone against cardiomyocyte injury induced by doxorubicin in vitro. BMC Complement. Altern. Med. 12:138. doi: 10.1186/1472-6882-12-138

Wang, X., Greilberger, J., Ledinski, G., Kager, G., Paigen, B., and Jürgens, G. (2004). The hypolipidemic natural product Commiphora mukul and its component guggulsterone inhibit oxidative modification of LDL. Atherosclerosis 172, 239-246. doi: 10.1016/j.atherosclerosis.2003.10.008

Wang, Y. G., Ma, Q. G., Tian, J., Ren, J., Wang, A. G., Ji, T. F., et al. (2016). Hepatoprotective triterpenes from the gum resin of Boswellia carterii. Fitoterapia 109, 266-273. doi: 10.1016/j.fitote.2015.12.018

Wang, Y. G., Ren, J., Wang, A. G., Yang, J. B., Ji, T. F., Ma, Q. G., et al. (2013). Hepatoprotective prenylaromadendrane-type diterpenes from the gum resin of Boswellia carterii. J. Nat. Prod. 76, 2074-2079. doi: 10.1021/np400526b

Weber, C. C., Reising, K., Müller, W. E., Schubert-Zsilavecz, M., and Abdel-Tawab, M. (2006). Modulation of Pgp function by boswellic acids. Planta Med. 72, 507-513. doi: 10.1055/s-2006-931536

Wu, J., Xia, C., Meier, J., Li, S., Hu, X., and Lala, D. S. (2002). The hypolipidemic natural product guggulsterone acts as an antagonist of the bile acid receptor. Mol. Endocrinol. 16, 1590-1597. doi: 10.1210/mend.16.7.0894

Xia, L., Chen, D., Han, R., Fang, Q., Waxman, S., and Jing, Y. (2005). Boswellic acid acetate induces apoptosis through caspase-mediated pathways in myeloid leukemia cells. Mol. Cancer Ther. 4, 381-388. doi: 10.1158/1535-7163.MCT-03-0266

Xiao, D., and Singh, S. V. (2008). z-Guggulsterone, a constituent of Ayurvedic medicinal plant C. mukul, inhibits angiogenesis in vitro and in vivo. Mol. Cancer Ther. 7, 171-180. doi: 10.1158/1535-7163.MCT-07-0491

Xiao, D., Zeng, Y., Prakash, L., Badmaev, V., Majeed, M., and Singh, S. V. (2011). Reactive oxygen species-dependent apoptosis by gugulipid extract of Ayurvedic medicine plant Commiphora mukul in human prostate cancer cells is regulated by c-Jun N-terminal kinase. Mol. Pharmacol. 79, 499-507. doi: $10.1124 / \mathrm{mol} .110 .068551$

Xu, H. B., Fu, J., Huang, F., and Yu, J. (2017). Guggulsterone sensitized drug-resistant human hepatocarcinoma cells to doxorubicin through a Cox-2/P-gp dependent pathway. Eur. J. Pharmacol. 803, 57-64. doi: 10.1016/j.ejphar.2017.03.045

Xu, H. B., Li, L., and Liu, G. Q. (2011). Reversal of multidrug resistance by guggulsterone in drug-resistant MCF-7 cell lines. Chemotherapy 57, 62-70. doi: $10.1159 / 000321484$

Xu, H. B., Shen, Z. L., Fu, J., and Xu, L. Z. (2014a). Reversal of doxorubicin resistance by guggulsterone of Commiphora mukul in vivo. Phytomedicine 21, 1221-1229. doi: 10.1016/j.phymed.2014.06.003

Xu, H. B., Xu, L. Z., Li, L., Fu, J., and Mao, X. P. (2012). Reversion of P-glycoprotein-mediated multidrug resistance by guggulsterone in multidrug-resistant human cancer cell lines. Eur. J. Pharmacol. 694, 39-44. doi: 10.1016/j.ejphar.2012.06.046

Xu, H. B., Xu, L. Z., Mao, X. P., and Fu, J. (2014b). Guggulsterone of Commiphora mukul resin reverses drug resistance in imatinib-resistant leukemic cells by inhibiting cyclooxygenase-2 and P-glycoprotein. Phytomedicine 21, 1004-1009. doi: 10.1016/j.phymed.2014.02.014

Xu, Y., Watanabe, T., Tanigawa, T., Machida, H., Okazaki, H., Yamagami, H., et al. (2010). Bile acids induce $c d x 2$ expression through the farnesoid $\mathrm{x}$ receptor in gastric epithelial cells. J. Clin. Biochem. Nutr. 46, 81-86. doi: 10.3164/jcbn.09-71

Y, J., Kamath, J. V., and Asad, M. (2006). Effect of hexane extract of B. serrata oleo-gum resin on chemically induced liver damage. Pak. J. Pharm. Sci. 19, 129-133.

Yadav, V. R., Prasad, S., Sung, B., Gelovani, J. G., Guha, S., Krishnan, S., et al. (2012). Boswellic acid inhibits growth and metastasis of human colorectal cancer in orthotopic mouse model by downregulating inflammatory, proliferative, invasive and angiogenic biomarkers. Int. J. Cancer 130, 2176-2184. doi: 10.1002/ijc.26251
Yamada, T., and Sugimoto, K. (2016). Guggulsterone and its role in chronic diseases. Adv. Exp. Med. Biol. 929, 329-361. doi: 10.1007/978-3-319-41342-6_15

Yamada, T., Osawa, S., Ikuma, M., Kajimura, M., Sugimoto, M., Furuta, T., et al. (2014). Guggulsterone, a plant-derived inhibitor of NF-TB, suppresses CDX2 and COX-2 expression and reduces the viability of esophageal adenocarcinoma cells. Digestion 90, 208-217. doi: 10.1159/000365750

Yang, J. Y., Della-Fera, M. A., and Baile, C. A. (2008). Guggulsterone inhibits adipocyte differentiation and induces apoptosis in 3T3-L1 cells. Obesity 16, 16-22. doi: 10.1038/oby.2007.24

Yang, J. Y., Della-Fera, M. A., Rayalam, S., Ambati, S., and Baile, C. A. (2007). Enhanced pro-apoptotic and anti-adipogenic effects of genistein plus guggulsterone in 3T3-L1 adipocytes. Biofactors 30, 159-169. doi: 10.1002/biof.5520300303

Yang, L., Broderick, D., Jiang, Y., Hsu, V., and Maier, C. S. (2014). Conformational dynamics of human FXR-LBD ligand interactions studied by hydrogen/deuterium exchange mass spectrometry: insights into the antagonism of the hypolipidemic agent Z-guggulsterone. Biochim. Biophys. Acta 1844, 1684-1693. doi: 10.1016/j.bbapap.2014.06.007

Yang, M. H., Lee, K. T., Yang, S., Lee, J. K., Lee, K. H., Moon, I. H., et al. (2012). Guggulsterone enhances antitumor activity of gemcitabine in gallbladder cancer cells through suppression of NF-кB. J. Cancer Res. Clin. Oncol. 138, 1743-1751. doi: 10.1007/s00432-012-1254-7

Youn, H. S., Ahn, S. I., and Lee, B. Y. (2009). Guggulsterone suppresses the activation of transcription factor IRF3 induced by TLR3 or TLR4 agonists. Int. Immunopharmacol. 9, 108-112. doi: 10.1016/j.intimp.2008.10.012

Yuan, H. Q., Kong, F., Wang, X. L., Young, C. Y., Hu, X. Y., and Lou, H. X. (2008) Inhibitory effect of acetyl-11-keto-beta-boswellic acid on androgen receptor by interference of $\mathrm{Sp} 1$ binding activity in prostate cancer cells. Biochem. Pharmacol. 75, 2112-2121. doi: 10.1016/j.bcp.2008.03.005

Zhang, J. H., Shangguan, Z. S., Chen, C., Zhang, H. J., and Lin, Y. (2016). Antiinflammatory effects of guggulsterone on murine macrophage by inhibiting LPS-induced inflammatory cytokines in NF-кB signaling pathway. Drug Des. Devel. Ther. 10, 1829-1835. doi: 10.2147/DDDT.S104602

Zhao, W., Entschladen, F., Liu, H., Niggemann, B., Fang, Q., Zaenker, K. S., et al. (2003). Boswellic acid acetate induces differentiation and apoptosis in highly metastatic melanoma and fibrosarcoma cells. Cancer Detect. Prev. 27, 67-75. doi: 10.1016/S0361-090X(02)00170-8

Zhong, F., Tong, Z. T., Fan, L. L., Zha, L. X., Wang, F., Yao, M. Q., et al. (2016). Guggulsterone-induced apoptosis in cholangiocarcinoma cells through ROS/JNK signaling pathway. Am. J. Cancer Res. 6, 226-237.

Zhong, F., Yang, J., Tong, Z. T., Chen, L. L., Fan, L. L., Wang, F., et al. (2015). Guggulsterone inhibits human cholangiocarcinoma Sk-ChA1 and Mz-ChA-1 cell growth by inducing caspase-dependent apoptosis and downregulation of survivin and Bcl-2 expression. Oncol. Lett. 10, 1416-1422. doi: 10.3892/ol.2015.3391

Zhou, X., Cai, J. G., Zhu, W. W., Zhao, H. Y., Wang, K., and Zhang, X. F. (2015). Boswellic acid attenuates asthma phenotype by downregulation of GATA3 via nhibition of PSTAT6. Genet. Mol. Res. 14, 7463-7468. doi: 10.4238/2015.July.3.22

Zhu, N., Rafi, M. M., DiPaola, R. S., Xin, J., Chin, C. K., Badmaev, V., et al. (2001). Bioactive constituents from gum guggul (Commiphora wightii). Phytochemistry 56, 723-727. doi: 10.1016/S0031-9422(00)00485-4

Conflict of Interest Statement: The authors declare that the research was conducted in the absence of any commercial or financial relationships that could be construed as a potential conflict of interest.

Copyright (c) 2018 Kunnumakkara, Banik, Bordoloi, Harsha, Sailo, Padmavathi, Roy, Gupta and Aggarwal. This is an open-access article distributed under the terms of the Creative Commons Attribution License (CC BY). The use, distribution or reproduction in other forums is permitted, provided the original author(s) and the copyright owner(s) are credited and that the original publication in this journal is cited, in accordance with accepted academic practice. No use, distribution or reproduction is permitted which does not comply with these terms. 